\title{
Review \\ Is Tissue Still the Issue? The Promise of Liquid Biopsy in Uveal Melanoma
}

\author{
Daniël P. de Bruyn 1,2,3, Aaron B. Beasley ${ }^{4}$, Robert M. Verdijk ${ }^{5,6,7}\left(\mathbb{D}\right.$, Natasha M. van Poppelen ${ }^{1,2,3}$ (D), \\ Dion Paridaens ${ }^{1,5}$, Ronald O. B. de Keizer ${ }^{5}$, Nicole C. Naus ${ }^{1,3}$, Elin S. Gray ${ }^{4} \mathbb{D}$, Annelies de Klein ${ }^{2,3}$, \\ Erwin Brosens ${ }^{2,3,+}$ (D) and Emine Kiliç ${ }^{1,3, *,+, \neq}$ on behalf of the Rotterdam Ocular Melanoma Study Group
}

check for updates

Citation: de Bruyn, D.P.; Beasley, A.B.; Verdijk, R.M.; van Poppelen, N.M.; Paridaens, D.; de Keizer, R.O.B.; Naus, N.C.; Gray, E.S.; de Klein, A.; Brosens, E.; et al. Is Tissue Still the Issue? The Promise of Liquid Biopsy in Uveal Melanoma. Biomedicines 2022, 10, 506. https:// doi.org/10.3390/biomedicines10020506

Academic Editor: Luca Falzone

Received: 25 January 2022

Accepted: 16 February 2022

Published: 21 February 2022

Publisher's Note: MDPI stays neutral with regard to jurisdictional claims in published maps and institutional affiliations.

Copyright: (C) 2022 by the authors. Licensee MDPI, Basel, Switzerland. This article is an open access article distributed under the terms and conditions of the Creative Commons Attribution (CC BY) license (https:// creativecommons.org/licenses/by/ $4.0 /)$.
1 Department of Ophthalmology, Erasmus MC Rotterdam, 3000 CA Rotterdam, The Netherlands; d.p.debruyn@erasmusmc.nl (D.P.d.B.); n.vanpoppelen@erasmusmc.nl (N.M.v.P.); d.paridaens@oogziekenhuis.nl (D.P.); n.naus@erasmusmc.nl (N.C.N.)

2 Department of Clinical Genetics, Erasmus MC Rotterdam, 3000 CA Rotterdam, The Netherlands; a.deklein@erasmusmc.nl (A.d.K.); e.brosens@erasmusmc.nl (E.B.)

3 Erasmus MC Cancer Institute, 3000 CA Rotterdam, The Netherlands

4 Centre for Precision Health, School of Medical and Health Sciences, Edith Cowan University, Joondalup, WA 6027, Australia; a.beasley@ecu.edu.au (A.B.B.); e.gray@ecu.edu.au (E.S.G.)

5 The Rotterdam Eye Hospital, 3011 BH Rotterdam, The Netherlands; r.verdijk@erasmusmc.nl (R.M.V.); r.dekeizer@oogziekenhuis.nl (R.O.B.d.K.)

6 Department of Pathology, Section Ophthalmic Pathology, Erasmus MC Rotterdam, 3000 CA Rotterdam, The Netherlands

7 Department of Pathology, Leiden University Medical Center, 2333 ZA Leiden, The Netherlands

* Correspondence: e.kilic@erasmusmc.nl; Tel.: +31-107030683

+ These authors contributed equally to this work, shared position.

$\ddagger \quad$ The Rotterdam Ocular Melanoma Study Group (ROMS) is a collaborative research group with members from the Rotterdam Eye Hospital, Departments of Ophthalmology, Pathology and Clinical Genetics, of the Erasmus MC, Rotterdam, The Netherlands.

Abstract: Uveal melanoma (UM) is the second most frequent type of melanoma. Therapeutic options for UM favor minimally invasive techniques such as irradiation for vision preservation. As a consequence, no tumor material is obtained. Without available tissue, molecular analyses for gene expression, mutation or copy number analysis cannot be performed. Thus, proper patient stratification is impossible and patients' uncertainty about their prognosis rises. Minimally invasive techniques have been studied for prognostication in UM. Blood-based biomarker analysis has become more common in recent years; however, no clinically standardized protocol exists. This review summarizes insights in biomarker analysis, addressing new insights in circulating tumor cells, circulating tumor DNA, extracellular vesicles, proteomics, and metabolomics. Additionally, medical imaging can play a significant role in staging, surveillance, and prognostication of UM and is addressed in this review. We propose that combining multiple minimally invasive modalities using tumor biomarkers should be the way forward and warrant more attention in the coming years.

Keywords: PET/CT; CT; US; OCT; exosomes; non-invasive; survival

\section{Introduction}

Uveal melanoma (UM) is a rare but life-threatening disease. The incidence of UM is mildly increasing, which is primarily due to the increased detection of small tumors [1]. This coincides with a trend towards non-surgical, eye-sparing therapeutic options, in which no tumor tissue is available [2], as shown in Figure 1. About $50 \%$ of the patients will eventually develop metastases, which are usually fatal within one year $[3,4]$. 


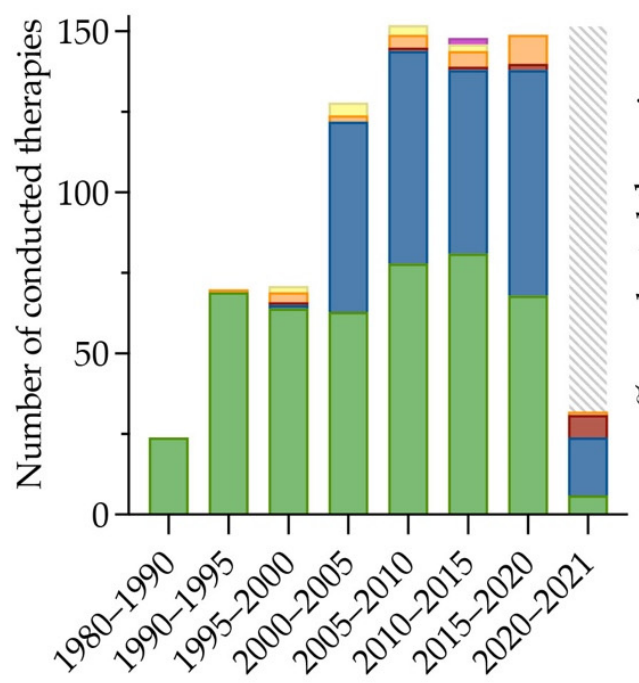

(a)

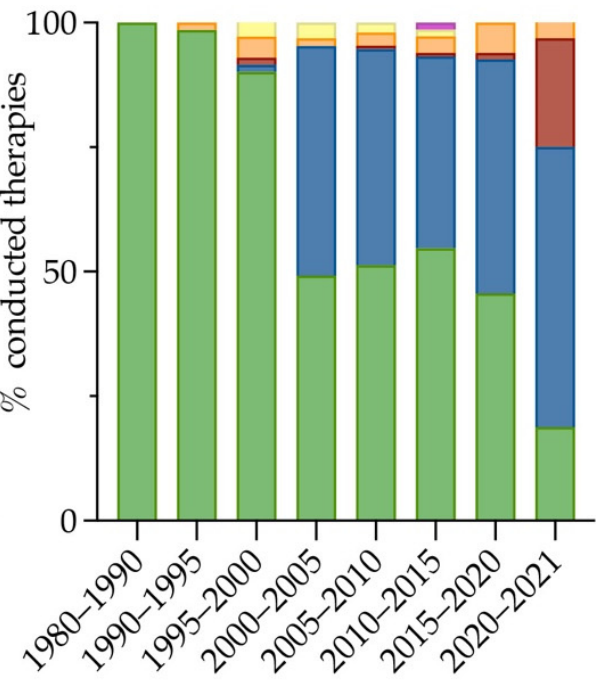

(b)

Figure 1. Overview of 774 UM-patients treated at the Erasmus MC and Rotterdam Eye Hospital, Rotterdam, The Netherlands from 1980 to 2021. At the Erasmus Medical Center, fractionated stereotactic radiotherapy (fSRT) was performed since December 1999 and proton beam therapy was available from January 2020. Plaque therapy was performed at the Leiden University Medical Center since January 1990. (a) the number and type of therapy conducted; and (b) the respective fraction of therapy type per time period. In 2020-2021, 24 patients were treated for UM. The gray and white striped bar marks the expected number of UMs in the Rotterdam Ocular Melanoma Study group (ROMS)-cohort from 2021 to 2025. Abbreviations: fSRT: fractionated stereotactic radiotherapy; PBT: proton beam therapy; TTT: transpupillary thermo therapy; PDT: photodynamic therapy.

Despite numerous initiated trials over the last decades, improvement in progression free survival (PFS) has been sparse. Some elongation of the time to metastases was reported after dendritic cell vaccination, in which high-risk (and monosomy 3) patients received vaccinations with dendritic cells transfected with glycoprotein 100 (gp100) and tyrosinase [5]. However, new systemic therapeutic options are still being explored. For example, immune checkpoint inhibitors and more specifically monoclonal antibodies that target programmed cell death protein 1 (PD-1) and cytotoxic T-lymphocyte-associated antigen 4 (CTLA-4) receptors and their ligands (e.g., Nivolumab (anti-PD-1 antibody) and Ipilumab (anti-CTLA-4 antibody). Inhibition of CTL-4 and PD-1 results in downregulation of regulatory $\mathrm{T}$ cells and a concurrent upregulation of T effector cells (T-helper cells). As a result, more cytokines are produced. These processes might explain the improvement in PFS and overall survival (OS) in multiple types of malignancy, including cutaneous melanoma (CM) [6]. As their efficacy has been proven in metastatic CM, immune checkpoint inhibitors have been tried in UM and the results are promising [7]. However, efficacy in UM tends to be lower, possibly due to a higher ratio of exhausted T-cells in immune infiltrates of UM metastases compared to CM [8]. Another promising therapeutic option in metastatic UM is Tebentafusp, a bispecific protein that redirects T-cells to attack gp100 expressing cells. After binding to peptide-human leukocyte antigen (HLA) complexes, polyclonal T-cells are recruited and activated for cluster of differentiation (CD) 3-mediated cytokine and cytolytic mediator release. As Tebentafusp redirects T-cells in specific HLA complexes, only patients with HLA-A*02:01 positive patients profit from the experimental therapy. Recently, patients receiving Tebentafusp had an elongated OS and PFS compared to the control group consisting of Pembrolizumab, Ipilumab, or Dacarbazine treatment (median OS: 21.7 months, vs. 16 months, respectively; median PFS: 3.3 months vs. 2.9 months, respectively) [9]. 
Chromosomal aberrations and gene mutations in UM that correspond with prognosis are well characterized. There are four distinct molecular subclasses, and their respective outcome has been identified [10,11]. The loss of BRCA1-Associated Protein 1 (BAP1) along with chromosome 3 loss and chromosome $8 \mathrm{q}$ gain is correlated to the worst prognosis, a mutation in splicing factor 3B subunit 1 (SF3B1) causes aberrant splicing due to the use of alternative branch points by the spliceosome complex and is associated with an intermediate metastatic risk, whereas Eukaryotic Translation Initiation Factor 1A X-Linked (EIF1AX) mutations will generally not result in metastases [12-14]. Furthermore, clinical parameters indicative for poor prognosis include higher age, higher mean basal tumor diameter and tumor thickness, extraocular spread, and ciliary body involvement [15].

Although metastatic risk is not influenced by intraocular biopsies [16], they harbor an inherent risk of complications, such as persistent hemorrhage requiring surgical intervention or rhegmatogenous retinal detachment (both in $1 \%$ of the fine needle aspiration biopsies (FNABs)). Rarer complications include seeding at the needle tract [17], extra-ocular extension of uveal melanoma [18], and endophthalmitis [19,20]. Furthermore, FNAB will not yield prognostic information in a substantial number of cases. Especially in smaller tumors $(<5 \mathrm{~mm}$ in height) and posteriorly located tumors is this the case [21]. In addition, worsening of visual acuity (VA) is reported in $13 \%$ of the patients who underwent FNAB [21] and the VA worsened in $42 \%$ of patients undergoing transvitreal retinochoroidal biopsy [22]. However, worsening of the VA could also be explained by tumor or radiation effects.

Disease progression surveillance without prior genetic knowledge will typically include a 6-monthly liver imaging (either ultrasound or magnetic resonance imaging) and liver function tests for all UM-patients. In the UK, liver screening has been estimated to cost the NHS between $£ 108.000$ and $£ 228.000$ yearly [23]. Knowledge of such prognostic genetic alterations may, therefore, lead to more individual and cost-effective follow-up strategies.

In summary, the emerging trend in therapeutic options, therapeutic studies, and the reticence regarding invasive biopsies highlight the need for effective and efficient surveillance and non-invasive prognostication. This review addresses liquid biopsies, with an emphasis on analysis of circulating tumor cells (CTCs), circulating tumor DNA (ctDNA), tumor derived exosomes, proteins, and metabolites. Additionally, medical imaging will be discussed in terms of potential prognostic value and clinical use.

\section{Liquid Biopsy}

The term liquid biopsy is a contradiction in terms as biopsies inherently refer to obtaining tissue. Nonetheless, the term beautifully comprises the intention of obtaining tumor information from (the content of) fluids. These blood-based liquid biopsies are minimally invasive, quick, and easy to conduct and undergo. The risks are next to none. When peripheral blood is used for diagnosing or prognostication, usually less than $20 \mathrm{~mL}$ is sufficient [24-26], which can be withdrawn easily in most, if not all, patients [27].

The possibilities for blood-based tumor biomarkers are vast and encompass, among others, (the cargo of) CTCs, DNA, RNA, exosomes, proteins, and metabolites.

\subsection{Circulating Tumor Cells}

CTCs were first described in 1869 by Dr. Thomas Ashworth, who saw the similarity of cells in the tumor and tumor cells circulating in blood. Since then, CTCs have been of interest in different fields of cancer [28,29]. CTCs are clones of the original tumor and in a heterogenous tumor, multiple, genetically, different CTCs could be found in the bloodstream [30]. Multiple studies have analyzed the genetic composition of CTCs. DNA [26], RNA [31,32], proteins [33], micro RNAs (miRNAs) [34], and metabolites [35] have been found in CTCs, albeit in low quantities.

The mechanism behind intravasation of these tumor cells is not yet fully understood. Two main hypotheses exist. On the one hand, a passive shedding of cells is postulated, where clumps of cells break off the primary tumor and will enter the bloodstream. On the other hand, an active transition of cells to a more mobile state through an epithelial to 
mesenchymal transition is hypothesized [33]. As such, solitary CTCs as well as clusters are present in blood.

Aceto et al. have shown, in breast and prostate cancer, that single CTCs are more abundant. However, single CTCs do not harbor the same metastatic potential as clusters of CTCs, which are comprised of an aggregation of neighboring cells from the primary tumor (i.e., oligoclonal cluster from primary tumor). These clusters broke off the primary tumor and entered the bloodstream. Mouse models showed a 23-50-fold increase in metastatic potential of CTC clusters compared to single CTCs [28]. These findings translate to humans, as worse OS and PFS were reported in patients with CTC clusters [28,36]. Additionally, it is important to note that the presence of circulating tumor cells do not necessarily represent a metastatic potential [28].

In 1993, over a century after Dr. Ashworth's discovery of CTCs, Tobal et al., among others [37,38], used reverse transcription PCR (RT-PCR) on the lysed cell pellet of $5 \mathrm{~mL}$ peripheral blood to detect transcripts of the tyrosinase gene, a gene encoding a protein crucial for melanin production and in normal conditions not present in blood, in the blood of UM-patients. They detected Tyrosinase transcripts in half of the UM-patients with metastatic disease and a quarter of the patients without metastases [38]. Since then, CTC isolation and characterization has progressed in UM.

\subsubsection{CTC Enrichment and Enumeration}

CTCs are rare, only a few tumor cells can be found in a single tube of peripheral blood from UM-patients with localized disease $[24,26,39,40]$. Therefore, sensitive and precise isolation methods are needed.

CTCs can be captured using different techniques, such as filtration-based or immunomagnetic, with the latter being more popular in UM research [26,40-42]. A combination of a microfluidic device containing immuno-affinity properties was also developed, in which a chip containing columns covered with epithelial cell adhesion molecule (EpCAM) antibodies can capture CTCs [43]. Filtration-based enrichment is based on the difference in size and compressibility of CTCs and (white) blood cells. Even though the diameter of non-hematological tumor cells varies, the mean diameter of nuclei originating from non-hematological metastases differs substantially from the diameter of lymphocytic nuclei (9.28 $\mu \mathrm{m}$ vs. $4.95 \mu \mathrm{m}(p<0.001)$, respectively) [44]. Immunomagnetic or affinity-based enrichment relies on the expression of tumor cell specific proteins on the cell membrane of CTCs [45]. Using filtration-based CTC enrichment, Mazzini et al. detected CTCs in 17 out of 31 non-metastatic patients. They showed no correlation between the presence of CTCs and clinical and histopathological prognostic parameters. They did report a significant difference in longest basal diameter, tumor height, PFS, and OS after stratifying patients in groups based on the detection of more versus less than 10 CTCs per $10 \mathrm{~mL}$ blood [42].

For capturing CTCs, immunomagnetic isolation is mostly used [24,26,39-41,46] in UM. The specificity of antibodies used herein is essential to capturing CTCs. Moreover, different antibody bound magnetic particles can be used for capturing CTCs and they have their own characteristics. Thermo Fisher DynaBeads (Thermo Fisher Scientific, Waltham, Massachusetts, United States) are spherical particles ranging from 1 to $5 \mu \mathrm{m}$. Due to their size, they have a relatively strong magnetic power. Dynabeads can be captured without a magnetic mesh or microchip [26]. However, the size of DynaBeads can complicate downstream analyses. Veridex ferrofluids are small, $100 \mathrm{~nm}$-sized, ferroparticles $\left(\mathrm{Fe}_{3} \mathrm{O}_{4}\right)$ and are labeled with antibodies (EpCAM or melanoma cell adhesion molecule (MCAM)). These ferrofluids are used in the closed, food and drug administration (FDA) approved system CellSearch (Menarini Sillicon Biosystems, Bologna, Italy), which complicates creating custom antibodybead combinations. However, it is the golden standard method for CTC isolation. The ferrofluids are incubated with a blood sample and the CTC will be drawn to the slide while other cells are discarded [47]. Another type of beads are Miltenyi magnetic-activated cell sorting (MACS) beads. They have a heterogeneous size ranging from 30-100 nm. They do not infer with flowcytometry or other fluorescent applications [48]. For capturing or 
depletion of bound cells to the magnetic particles, different columns with a magnetized matrix are required.

\section{CellSearch}

The CellSearch assay uses ferrofluids bound to MCAM to capture melanoma CTCs. Afterwards, they are stained for melanoma-associated chondroitin sulfate proteoglycan (MCSP) (melanoma cells), CD34 (endothelial cells) and CD45 (leukocytes) to differentiate between melanoma CTCs and other cells expressing MCAM. It was first developed for capturing CM cells, where $88 \%$ of spiked-in cell line cells was recovered. However, in patients, only in $23 \%(18 / 79)$ of the metastatic CM blood samples had $\geq 2$ CTCs per $7.5 \mathrm{~mL}$ blood [29] (Table 1). Other studies have used the same system and protocols for both localized and metastatic UM and CTCs were found more frequently, which could possibly be explained by more robust or abundant CTCs.

Table 1. Summary of CTC yield per bead-bound antibody (combination) used for isolating CTCs from peripheral blood in patients with either localized or metastatic UM. Median marked with an ${ }^{*}$ is calculated from available data. Abbreviations: MCSP: melanoma-associated chrondroitin sulfate proteoglycan; ABCB5: ATP-binding cassette sub-family B member 5; gp100: glycoprotein 100; MCAM: melanoma cell adhesion molecule.

\begin{tabular}{ccccc}
\hline \multirow{2}{*}{$\begin{array}{c}\text { Bead-Bound } \\
\text { Antibody Used }\end{array}$} & Disease Status & $\begin{array}{c}\text { CTC Count } \\
\text { Median (Range) }\end{array}$ & \multicolumn{2}{c}{ Detection Rate } \\
\cline { 4 - 5 } & & n. & \% \\
\hline \multirow{2}{*}{ MCSP } & Localized & $2.5(1-5) / 50 \mathrm{~mL}$ & $10 / 52$ & $19 \%[49]$ \\
& Localized & $1(1-8) / 50 \mathrm{~mL}$ & $13 / 94$ & $14 \%[50]$ \\
& Localized & $2(1-37) / 8 \mathrm{~mL}^{*}$ & $18 / 26$ & $69 \%[26]$ \\
\hline ABCB5, gp100, & Localized & $3(1-89) / 8 \mathrm{~mL}$ & $37 / 43$ & $86 \%[51]$ \\
MCAM, MCSP & & $3.5(1-10) / 10 \mathrm{~mL}$ & $29 / 31$ & $94 \%[41]$ \\
\hline CD63 and gp100 & Localized & $2(1-3) / 7.5 \mathrm{~mL}$ & $4 / 8$ & $50 \%[40]$ \\
\hline & Localized & $1.5(1-3) / 10 \mathrm{~mL} *$ & $8 / 20$ & $40 \%[24]$ \\
MCAM & Localized & $2(1-38) / 10 \mathrm{~mL}^{*}$ & $13 / 19$ & $68 \%[24]$ \\
& Metastatic & $3(1-20) / 7.5 \mathrm{~mL}^{*}$ & $12 / 40$ & $30 \%[39]$ \\
\hline
\end{tabular}

In localized disease, $50 \%$ of the patients had detectable CTCs, with a median of 2 CTCs per $7.5 \mathrm{~mL}$ peripheral blood [40]. Anand et al. detected $1.83 \mathrm{CTCs}$ (mean) in $10 \mathrm{~mL}$ peripheral blood in 8 of 20 analyzed patients (Table 1) and the CTC count correlated to worse prognostic factors as monosomy 3 and $8 q$ gain and ultimately correlates independently to a worse OS. Additionally, CTC enumeration was performed in parallel to conventional imaging (computed tomography (CT) or magnetic resonance imaging (MRI) of the abdomen). They had found an increase in CTCs prior to imaging in $60 \%(3 / 5)$ of the patients who developed metastases, in the other two patients who developed metastases no CTCs were recovered [24].

In metastatic disease, the CTC count was higher, 3 (median) CTCs per $7.5 \mathrm{~mL}$, but CTCs were detected in fewer patients (30\%) [39] (Table 1). Moreover, Bidard et al. found a correlation between CTC count and tumor volume $\left(\mathrm{R}^{2}=0.28, p=0.005\right)$, and subsequently tested ctDNA levels $\left(\mathrm{R}^{2}=0.63, p<0.0001\right)$. Surprisingly, two patients with high CTC count (12 and $20 \mathrm{CTCs} / 7.5 \mathrm{~mL}$ ) had end-stage disease for which they received palliative care shortly after phlebotomy, but CTC count was not found as an independent prognostic factor [39]. On the other hand, Anand et al. observed a worse OS in patients with detectable CTCs and OS was correlated with CTC count. They reported a mean of 9 CTCs per $10 \mathrm{~mL}$ blood in 13 of 19 analyzed patients [24]. 


\section{MACS}

Ulmer et al. combined Miltenyi microbeads (Miltenyi Biotec, Bergisch Gladbach, North Rhine-Westphalia, Germany) with MCSP and 2.5 (median) CTCs were found per $50 \mathrm{~mL}$ heparinized peripheral blood in 19\% of UM-patients with localized disease [49] (Table 1). Using the same protocol, their group analyzed the presence of CTCs before and after primary treatment modalities for UM (enucleation, endoresection, Ruthenium-plaque, stereotactic radiotherapy, and transpupillary thermotherapy), in which they did not observe a difference [50].

\section{DynaBeads}

In 2014, Tura et al. modified and enhanced the protocol previously published by CoolLartigue et al. [52] in which bead-bound antibodies against CD63 and gp100 were used. Using these two markers, they detected CTCs in $93.6 \%$ (median: 3.5 cells per $10 \mathrm{~mL}$ whole blood) of patients harboring UM without clinically detectable metastases [41]. Beasley et al. first also used MCSP alone and detected CTCs in 69\% (18/26) of patients with primary UM. They did not find a correlation between the quantity or presence of CTCs and histopathologic or genetic prognostic parameters [26]. More recently, their follow-up study using a multimarker approach (ATP-binding cassette sub-family B member 5 (ABCB5), gp100, MCAM, and MCSP) detected a median of 3 CTCs in $86 \%(37 / 43)$ of localized cases from $8 \mathrm{~mL}$ of blood (Table 1) with the levels of CTCs correlating with shorter PFS and OS [51]. The detection rate had increased by adding melanoma-specific antibodies to their custom assay, which could mean not all UM CTCs express MCSP. The difference in survival characteristics could be explained by these other subtypes of CTCs that were potentially not captured previously, along with an increase in sample size.

When looking at the different bead-types and antibodies used, most studies indicate a worse prognosis when more CTCs are detected.

\subsubsection{CTC Characterization}

After capturing and isolating individual CTCs, different approaches have been used for characterization of CTCs. Proteins in CTCs can be studied by immunostaining as was shown by Campos et al. who used breast tumor cells that were spiked in and recovered from peripheral blood. The proteins HER2/NEU and TOP2A were identified and quantified and are correlated with Herceptin and Anthracycline therapy response, respectively [53,54]. Showing the clinical relevance of immunostaining and characterizing of CTCs. Other approaches include shallow whole genome sequencing (sWGS), fluorescence in situ hybridization (FISH) and transcriptomics.

\subsubsection{CTC Genotyping}

Copy Number Variations (CNVs) can be analyzed by whole genome and exome sequencing in CTCs isolated from peripheral blood of small cell lung cancer patients [55]. As specific CNV-profiles correlate to survival, this gives opportunity to minimally invasive risk stratification $[14,55]$. Sadly, in UM, CTCs are found less abundantly, complicating downstream analyses.

Therefore, low-input sequencing techniques or whole genome amplification is needed [26], which introduces technical artifacts [30]. For example, allelic dropouts after amplification occur regularly [56]. To distinguish true mutations from (whole genome) amplification artifacts, DNA barcodes can be added to the original DNA alleles prior to amplification. More recently an amplification free method has been introduced. Using molecular barcodes on DNA alleles, multiple samples can be pooled for library preparation. Afterwards, genes of interest were sequenced with high concordance to the original tumor [57].

In UM, chromosomal aberrations are correlated to progression free survival [11,12]. Ideally, CNV-profiles derived from CTCs will harbor the same characteristic aberrations as the primary UM tumor and CNV-profiles obtained from CTCs, either using sWGS or FISH, can be used for prognostication [26,46] (Figure 2). Historically, next generation sequencing 
performed on individual single cells has been difficult. Nonetheless, several studies were successfully conducted, giving insight in CTC biology.

Primary tumor. $0.37 \mathrm{x}$

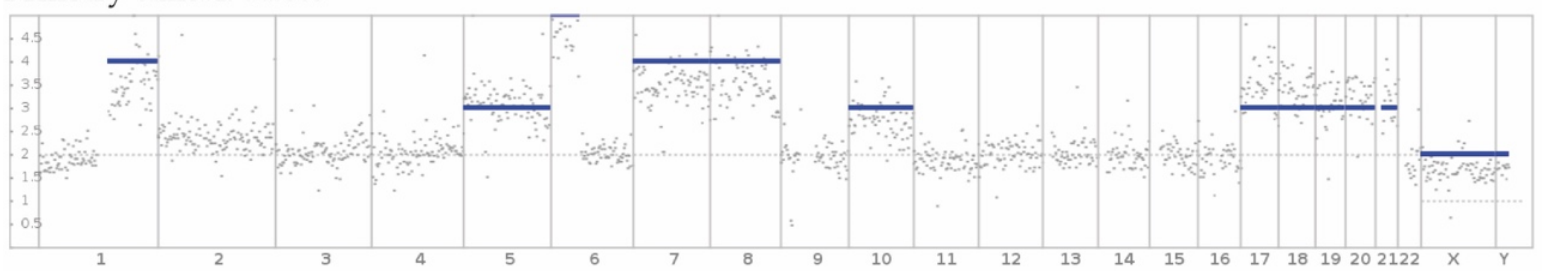

CTC. $0.30 \mathrm{x}$

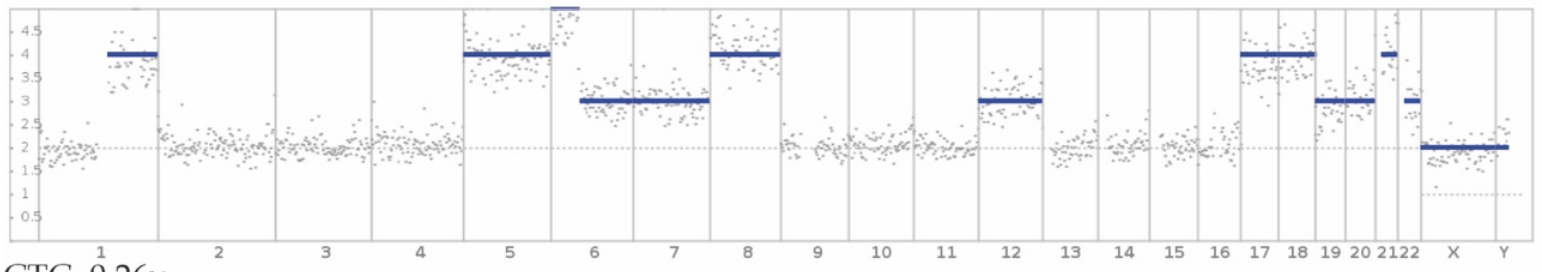

CTC. $0.26 x$

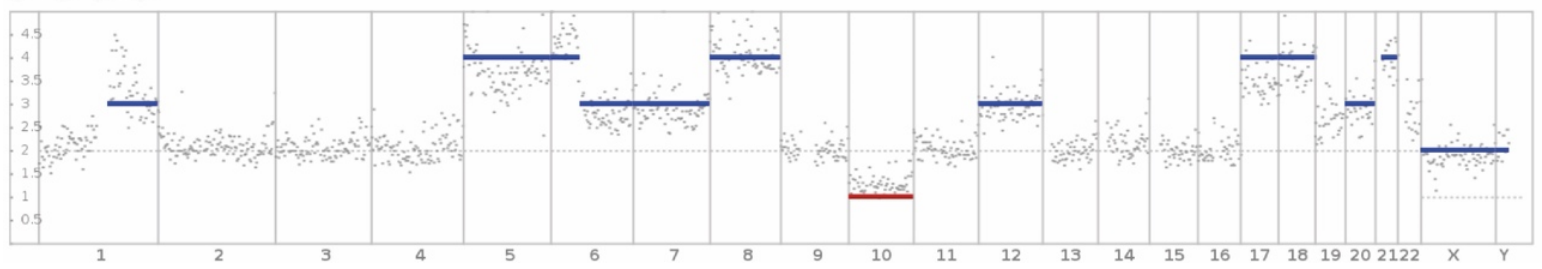

Figure 2. Modified from Beasley et al. [26] showing CNV-profiles derived from the primary tumor (FFPE tissue) and CTCs isolated from $10 \mathrm{~mL}$ peripheral blood of the same patient after whole genome amplification and shallow Whole Genome Sequencing (genomic coverage: $0.37 \times, 0.30 \times$ and $0.26 \times$, respectively).

In 2012, single CTC transcriptomics was performed with Switching Mechanism at $5^{\prime}$ end of RNA Template (SMART)-seq, using template switching. This improved the full-length coverage (from $3^{\prime}$ to $5^{\prime}$ ) to $40 \%$, compared to older techniques and coverage of all expressed genes came to $25 \%$ from $10 \mathrm{pg}$ of starting material [58]. Using a novel microfluidic chip to minimize cell loss prior to sequencing, Shi et al. have improved coverage and retrieved adequate expression data using SMART-seq2 library preparation, but they needed a minimum of 10 spiked-in CTCs [59]. Interestingly, Gkountela et al. have additionally discovered different cell states in single circulating breast cancer cells compared to CTC-clusters, which have a bigger metastatic potential. They also used SMART-seq2 library preparation on pooled CTCs and CTC-clusters and describe an upregulation of cell-cell junction components and a higher proliferation rate in CTC-clusters [36].

From the content of just over one cell, Lang et al. have successfully produced endto-end RNA libraries, using Ovation single cell RNA-seq. They concurrently stratified the primary tumor (using the prediction analysis for microarrays for breast carcinoma signatures: Nanostring PAM50 (Nanostring, Seattle, WA, USA)). The expression profiles in these single CTCs were highly discordant to the matched PAM50 signatures of the primary tumor, suggesting that they cannot be used for noninvasive prognostication and the authors explained the discordance as a difference in biologic processes present in a CTC compared to cells in their tumor environment [60].

Epigenetic regulation is a big factor in regulation of expression, which can also be explored in CTCs using whole genome bisulfite sequencing. This transforms unmethylated cytosines into uracil prior to sequencing and are ultimately read as thymines, whereas methylated regions retain their cytosines. Afterwards, methylated and unmethylated regions can be elucidated. Gkountela et al. have uncovered an enrichment of stemness 
related transcription factors regulating proliferation and pluripotency in CTC-clusters, compared to single CTCs, corresponding to their findings in RNA expression [36].

\subsection{Circulating Tumour DNA}

Cell-free DNA (cfDNA) circulates through the body and is either actively secreted by cells or is the result of cell death [61]. These physiological processes are naturally occurring [62] and cfDNA levels rise after pathologies, such as stroke, auto-immune disease, trauma, myocardial infarction, or cancer [63]. In cancer, ctDNA is released by tumor cells through apoptosis, necrosis, or active secretion [61]. Subsequently, mutations of the primary tumor can be retrieved in ctDNA [26,64]. However, the ctDNA fraction is low and accounts for $<0.1-10 \%$ of cfDNA in a patient harboring a malignancy [65]. As such, the low fraction of ctDNA can make detection of the driver gene mutations or copy number variations difficult [66].

Circulating DNA is fragmented; cfDNA-fragments are usually between 120-220 bp long. This coincides with the length of a DNA strand wrapped around a nucleosome plus $20 \mathrm{bp}$ of linker DNA bound to histone H1 [67]. ctDNA is more fragmented, with an enrichment of 90-150 bp ctDNA fragments, giving opportunity for in-silico or in-vitro enrichment of ctDNA [25].

Studies have shown a rise in cfDNA in patients harboring a malignancy, which could add prognostic value $[68,69]$. However, physiological processes could equally elevate cfDNA levels [68].

\subsubsection{Clinical Use of ctDNA in UM}

In UM, primary driver mutations are activating and mutually exclusive. In over $95 \%$ of the cases, somatic hotspot-mutations occur in G-protein $\alpha$ subunits $\mathrm{Q}$ and 11 (GNAQ and GNA11, respectively), cysteinyl Leukotriene Receptor 2 (CYSLTR2) or phospholipase $C$ beta 4 (PLCB4) $[3,70,71]$. Due to homogeneity in primary driver mutations, single mutation assays, albeit multiplexed, are efficient and feasible for disease detection and monitoring [64,70]. Tumor size, disease burden and ctDNA levels in primary and metastatic $\mathrm{UM}$ have been correlated to ctDNA levels of mutated primary driver genes [70,72].

Of the secondary driver genes (BAP1, SF3B1 and EIF1AX), only mutations in SF3B1 are suited for hotspot-mutation analysis. SF3B1 mutations result commonly in a missense replacing the arginine at position $625[11,12,73]$. Mutations in $B A P 1$, which comprises $50 \%$ of UM tumors, are loss of function mutations. They are found throughout the gene and can even encompass the deletion of one or more exons of the BAP1 gene [12]. EIF1AX mutations are, as the SF3B1 mutations, gain or change of function mutations. However, these mutations occur not at a single amino acid, but are spread out five to ten amino acids of the N-terminal region of the protein [14]. This results in only a possibility for SF3B1 mutations to be found using single hotspot-mutation analysis. Considering the prevalence of SF3B1 mutations (SF3B1 mutations occur in 24\% of UM-tumors [12]), in about a quarter of the UM-patients, the secondary driver mutation could be uncovered. When multiple techniques are combined in which either BAP1 or EIF1AX mutations can be discovered, mutation analysis for SF3B1 mutations can be a valuable addition.

UMs are sometimes difficult to distinguish from naevi. Especially when risk factors for potential malignant transition are present. These risk factors include the presence of subretinal fluid, orange pigment, tumor thickness $>2 \mathrm{~mm}$, peripapillary location, visual symptoms, and ultrasonographic hollowness [74]. An overlap between naevi with risk factors for malignant transition and small UM-tumors exist and make it hard to distinguish these groups. Moreover, naevi can harbor the same primary driver mutations in GNAQ or GNA11 as UMs do, without malignant transformation. Elevated levels of mutated cfDNA are highly correlated to malignancy and clinical risk factors for UM [75]. Therefore, circulating DNA harboring primary driver mutations could provide information of malignant transformation of these lesions and can be used for follow-up of naevi at risk. 
Treatment effects can be evaluated and monitored by analyzing ctDNA. For example, protein kinase $\mathrm{C}$ inhibitors have been tested in metastatic UM and treatment response correlated with lower ctDNA at endpoint [70]. Beasley et al. 2018 found a rise in ctDNA prior to radiologic confirmation of metastases in standard patient care [26]. Additionally, Le Guin et al. analyzed cfDNA in blood samples from 135 patients of which 19 developed metastases and two a local recurrence. In 106 patients, no ctDNA was detected at any time. From the patients with disease progression, 17 of 21 patients had detectable ctDNA $>5$ months after treatment (irradiation) and a spike in ctDNA was observed two to ten months prior to radiologic confirmation. Moreover, the presence of ctDNA was linked to disease progression with $80 \%$ sensitivity and $96 \%$ specificity [76], suggesting earlier and less burdensome detection of metastases and a potential ability of earlier treatment.

\subsection{2. ctDNA Genotyping}

Besides disease monitoring, ctDNA could be used for minimally invasive CNVprofiling and, thus, in the case of UM, provide valuable prognostic information, as the patients' prognosis is highly concordant to certain chromosomal aberrations in UM.

As stated earlier, ctDNA fragments are smaller than cfDNA. The fragmentation can be used for enrichment of ctDNA. Mouliere et al. have evaluated in silico size selection (selecting fragments of 90-150 bp after paired-end sequencing) and in-vitro size selection (using a microfluidic device), in which the in-vitro selection provided minimally invasive CNV-profiles from ctDNA in patients with ovarian cancer after sWGS [25]. Different malignancies can provide varying proportions of short (ctDNA) fragments in cfDNA [25,77]. Thus, the fragment size distribution of ctDNA in blood of UM-patients should be elucidated for enrichment prior to genotyping. In metastatic breast and prostate cancer, CNV-profiles were also obtained from ctDNA, where ultra sWGS, with a genomic coverage of $0.1 \times$, was performed on three to $20 \mathrm{ng}$ cfDNA. CNV-profiles from ctDNA were highly concordant to metastatic laesions (Spearman $\rho=0.763$ [78]) from a minimum tumor fraction of $10 \%$ [78,79]. However, $10 \%$ tumor fraction in blood is not feasible for UM confined to the eye $[26,70,76]$, meaning further enrichment of short fragments is necessary in UM.

\subsection{Extracellular Vesicles}

Extracellular vesicles (EVs) are nano-sized particles secreted by both healthy and pathological cells (i.e., cancer cells), comprising of microvesicles and exosomes. They are being used for intercellular communication [80]. Microvesicles (or ectosomes) originate from the plasma membrane and are formed by outward budding and fission, followed by release of these vesicles. The diameter ranges from 50 to $1000 \mathrm{~nm}$ [81]. Microvesicles can contain DNA, messenger RNA (mRNA), miRNA, and proteins [82-84]. EVs are involved in cell-cell signaling and modulation of the extracellular environment [81,84]. Moreover, EVs derived from tumor cell lines can drive an oncogenic shift in which proliferation is upregulated after invasion of the target cell. For example, Tsering et al. observed tumor growth after treating BRCA1-deficient fibroblasts with UM-derived EVs in mice [84].

Furthermore, EVs shed by tumor cells have enriched proteomic profiles involved in endocytosis, cell-cell signaling and focal adhesion and metastatic niche formation in UM [84]. Specific upregulated proteins in EVs originating from UM cells include Vimentin [84], melanoma-associated antigens D1 and D2 (MAGED1 \& 2) [84], and melanoma antigen (MLANA) [84]. For minimally invasive prognostication, the focus should shift towards characterization of tumor derived microvesicles in patients' serum.

\subsection{Exosomes}

Exosomes are discoid vesicles originating from endosomes and they are 30-150 nm in diameter. Some debate exists about the DNA load of exosomes. Some may argue that exosomes contain double stranded DNA (dsDNA). Thakur et al. uncovered dsDNA in a small subset of murine melanoma exosomes. Whole genome sequencing of exosomal dsDNA gave an unbiased coverage of the entire genome [85]. Takahashi et al. have also 
created unbiased CNV-profiles and even reported a homeostatic DNA secretion function for exosomes, in which exosome secretion inhibits aberrant immune response by secreting excess cytoplasmic DNA [86]. On the other hand, Jeppesen et al. were unable to detect dsDNA in exosomes. Concurrently, no DNA binding histones were found within (CD63 or CD83 positive) exosomes. As such, they concluded that DNA must be present on the vesicle membrane [87]. The debate whether exosomal DNA is on the membrane or within the vesicles is not settled. Despite this uncertainty, adequate CNV-profiles have been obtained using exosomal DNA and they could be used as a future biomarker.

Less debate exists about exosomes containing proteins, miRNA, and mRNA $[80,87,88]$. Several isolation techniques have been developed; however, no technique can purely isolate exosomes [89]. Capture techniques include: ultracentrifugation [80,90], (bead-bound) immuno-affinity [87], and size exclusion chromatography [91]. In UM, ultracentrifugation is mostly used and hereafter exosomes are commonly gold-coated and visualized using scanning electron microscopy [88]. Afterwards, exosomes are verified by expression of endosomal proteins programmed cell death 6-interacting protein (ALIX), Lysosome-associated membrane glycoprotein 1 (LAMP1) and CD63 [88]. Inflammation related proteomic profiles of exosome cargo have been analyzed by isolating exosomes via ultracentrifugation. Specific interleukins (IL-2, IL-11, IL12(p40) and IL-27) were upregulated in metastatic UM, compared to primary UM. These interleukins are involved in both pro and anti-tumor response. IFN- $\gamma$ was also found upregulated in exosomes derived from metastatic disease, which is correlated to metastases and overall more extensive disease [92]. As IFN- $\gamma$ was highly upregulated in only the metastatic patients, this is potentially an exosomal marker for monitoring disease progression.

UM derived exosomes have not yet been studied elaborately. Eldh et al. [88] isolated exosomes directly from the liver circulation in metastatic UM-patients. During isolated liver perfusion, perfusate was collected and exosomes were pelleted by ultracentrifugation. In addition to a higher quantity of exosomes, distinct miRNA patterns were found in patients versus healthy controls. MiRNAs are small RNA molecules that bind to the $3^{\prime}$ untranslated regions of mRNA and inhibit translation of these mRNAs and, therefore, regulate protein production [93]. For miRNA expression, the brain cancer related miRNA panel on the RT ${ }^{2}$ miRNA PCR array (Qiagen) is used. Upregulated miRNAs include miR-107, -124, -210, $-320 a,-370$, and $-486-5 p$ [88]. miR-21, $-34 a$, and -146a were found in exosomes captured from vitreous humor and peripheral blood and validated in UM-tissue [94].

MiRNAs provide valuable insights into the epigenetic regulation by exosomes. However, both studies only addressed upregulation between healthy individuals and UMpatients. Subsequently, no differentiation can be made between the low and high-risk UM-patients. Moreover, as the miRNA patterns do not overlap between both studies, uncertainty rises for the ability of these miRNAs as biomarkers.

\subsection{Micro RNA}

Circulating miRs were also isolated and sequenced directly from plasma and differentially expressed miRs could be used as a noninvasive prognostic tool for detection of (high-risk) UM. Furthermore, serum miRNAs were proposed as a surrogate marker for CTCs in breast cancer as capturing and isolating CTCs can be difficult because certain miRNAs were upregulated in CTC-positive patients with breast cancer [95].

In tumor tissue, the concentration of tumor derived miRNAs is higher than in peripheral blood. Smit et al. [96] have investigated miRNA expression using an Ion Proton sequencer (Life technologies) in high-risk tumors, consisting of BAP1-mutated tumors and absent BAP1 expression, intermediate-risk tumors, consisting of SF3B1-mutated tumors, and low-risk tumors, consisting of EIF1AX-mutated tumors. They reported an upregulation of miR-16-5p, -17-5p, -21-5p, -132-5p, and -151a-3p in high-risk tumors, while miR-99a$3 p,-101-3 p,-181 a-2-3 p,-181-5 p,-378 d,-1537-3 p$, and miRNA precursor let-7c-5p were downregulated in these high-risk tumors [96]. 
Multiple groups have identified differential expression in miRNAs using different techniques from plasma isolated from peripheral blood. Using quantitative RT-PCR, 6 monosomy 3 UM-patients were followed and miRs were analyzed at of disease and metastasis. At time of metastasis miR-20a, -125b, -146a, -155, and -223 were upregulated and miR-181a was downregulated [97]. Triozzi et al. [98] analyzed the expression of 674 miRs in tumor tissue and plasma between monosomy and disomy 3 UM-patients using the HTG quantitative nuclease protection assay (qNPA). One upregulated miR in tumor tissue was also found upregulated in plasma: miR-92b $(p<0.02)$ [98]. Using a Taqman low density array (TLDA) including 754 miRNAs, MiR-181a was found upregulated in plasma, while downregulated in tumor tissue. MiR-21, found upregulated in exosomes of UMpatients compared to healthy controls [94] and upregulated in tumor tissue of high-risk UM compared to low and intermediate-risk tumors [96], was not differentially expressed in plasma of monosomy and disomy 3 patients [98]. MiR-20a was not found differentially expressed by Triozzi et al., when Achberger et al. found an increase at time of metastasis. Furthermore, Achberger found a downregulation of miR-181a in metastatic disease, while Triozzi et al. found an upregulation in monosomy 3. Whereas in tumor tissue of high-risk UM miR-181-5p and miR-181a-2-3p were both downregulated [96]. Both studies show an upregulation of miR-223 in plasma of high-risk or metastatic patients. Ragusa et al. reported an increase of miR-618 in UM-patient derived exosomes from vitreous humor and plasma isolated from peripheral blood, while miRNAs isolated directly from vitreous humor showed a decrease of miR-618 in UM-patients versus healthy controls [94]. Table 2 shows a summary of the blood-derived miRNAs, their involvement in (uveal) melanoma and its up or downregulation in UM, high-risk or metastatic patients compared to either healthy individuals, low metastatic risk, or non-metastatic patients.

The advantages of miRs as biomarkers encompass a long half-life, due to in part the incorporation in EVs, easy accessibility through liquid biopsies, and high specificity and sensitivity [99-102]. miRNAs can have opposite functions based on the context and disease in which they are studied, which makes interpreting study results difficult. Furthermore, studies make use of miRNA panels, hybridization-based arrays as well as (next generation) sequencing technologies. These techniques all have differences in analyzed miRNAs and sensitivity thereof. Differentially expressed miRNAs could provide prognostic information, but the differences in disease state, or context, and used techniques make cross-study outcome statistical comparison and replication challenging.

In the context of UM, miRNAs should show concordant expression between cohorts with the same disease state; however, expression patterns do not overlap between monosomy 3 patients (i.e., high-risk of metastasis) and already metastasized tumors. The true reasons for the distinction in miRNA between high-risk localized and already metastasized UM must be elucidated, before making miRNA expression a clinically viable minimally invasive biomarker. 
Table 2. Regulatory effects in cutaneous or uveal melanoma of upregulated microRNA found in plasma and extracellular vesicles in vitreous humor, peripheral blood, blood collected during isolated liver perfusion, and/or UM-tissue. Expression compared to: UM-patients versus healthy controls; Metastatic patients versus localized disease; Monosomy 3 versus disomy 3. Abbreviations: DE: differentially expressed; RT-PCR: reverse transcription polymerase chain reaction; EVs: extracellular vesicles; TLDA: Taqman low density array; $\mathrm{RT}^{2}$ array: Qiagen $\mathrm{RT}^{2}$ miRNA PCR array (brain cancer panel); qNPA: HTG molecular diagnostics quantitative nuclease protection assay; VH: vitreous humor.

\begin{tabular}{|c|c|c|c|c|}
\hline microRNA & Expression & $\begin{array}{c}\text { Found in Tissue } \\
\text { Type }\end{array}$ & $\begin{array}{l}\text { Sequencing } \\
\text { Technique }\end{array}$ & Modulatory Effect \\
\hline miR-20a [97] & $\begin{array}{l}\text { Upregulated } \\
\text { in UM-patients } \\
\text { and metastatic } \\
\text { patients }\end{array}$ & Plasma & RT-PCR & \multirow{2}{*}{$\begin{array}{c}\text { Promotes cell proliferation and migration by } \\
\text { modulation of the cell cycle, focal adhesion and } \\
\text { phosphoinositide 3-kinase (PI3K)-AKT signaling } \\
\text { pathway }[103,104] \text {. }\end{array}$} \\
\hline miR-20a [98] & $\begin{array}{l}\text { Not DE } \\
\text { between } \\
\text { monosomy and } \\
\text { disomy } 3\end{array}$ & Plasma & RT-PCR & \\
\hline miR-21 [94] & $\begin{array}{c}\text { Upregulated } \\
\text { in UM-patients }\end{array}$ & $\begin{array}{l}\text { EVs: vitreous } \\
\text { and FFPE } \\
\text { UM-Tissue }\end{array}$ & TLDA & \multirow{2}{*}{$\begin{array}{l}\text { Promotes tumor growth, invasion, and metastasis, by } \\
\text { regulation of tumorsuppressors (p53) [105] in CM and } \\
\text { UM [106-108]. }\end{array}$} \\
\hline miR-21 [98] & $\begin{array}{l}\text { Not DE } \\
\text { between } \\
\text { monosomy and } \\
\text { disomy } 3\end{array}$ & Plasma & RT-PCR & \\
\hline miR-34a [94] & $\begin{array}{c}\text { Upregulated } \\
\text { in UM-patients }\end{array}$ & $\begin{array}{l}\text { EVs: vitreous } \\
\text { and FFPE } \\
\text { UM-Tissue }\end{array}$ & TLDA & $\begin{array}{c}\text { PDL-1 is regulated by p53 via miR-34, causing immune } \\
\text { evasion: UL16-binding protein } 2 \text { (ULBP2) is } \\
\text { downregulated causing a diminished cell recognition } \\
\text { by NK-cells }[109,110] \text {. }\end{array}$ \\
\hline miR-92b [98] & $\begin{array}{l}\text { Upregulated in } \\
\text { monosomy } 3\end{array}$ & Plasma & RT-PCR & $\begin{array}{l}\text { Promotes proliferation and migration in hepatocellular } \\
\text { carcinoma. No mechanistic information is known in } \\
\text { (U)M [111]. }\end{array}$ \\
\hline miR-107 [88] & $\begin{array}{c}\text { Upregulated } \\
\text { in UM-patients }\end{array}$ & $\begin{array}{l}\text { EVs: isolated } \\
\text { liver } \\
\text { perfusate }\end{array}$ & $\mathrm{RT}^{2}$ array & $\begin{array}{c}\text { Inhibits cell proliferation, migration, and invasion in } \\
\mathrm{CM} \text {. Highest expression is seen in metastatic } \\
\text { melanoma [112]. }\end{array}$ \\
\hline miR-124 [88] & $\begin{array}{l}\text { Upregulated } \\
\text { in UM-patients }\end{array}$ & $\begin{array}{l}\text { EVs: isolated } \\
\text { liver } \\
\text { perfusate }\end{array}$ & $\mathrm{RT}^{2}$ array & $\begin{array}{c}\text { Homeobox } 11 \text { (HOXA11)-antisense RNA promotes } \\
\text { proliferation and invasion by inhibiting miR-124 in } \\
\text { UM [113]. MiR-124 inhibits proliferation, migration, } \\
\text { invasion and promotes apoptosis of melanoma } \\
\text { cells [114]. }\end{array}$ \\
\hline miR-125b [97] & $\begin{array}{l}\text { Upregulated } \\
\text { in metastatic } \\
\text { disease }\end{array}$ & Plasma & RT-PCR & $\begin{array}{l}\text { Induces apoptosis and inhibits proliferation and } \\
\text { migration of CM cell line cells by targeting neural cell } \\
\text { adhesion molecules (NCAM) [115]. }\end{array}$ \\
\hline
\end{tabular}


Table 2. Cont.

\begin{tabular}{|c|c|c|c|c|}
\hline microRNA & Expression & $\begin{array}{c}\text { Found in Tissue } \\
\text { Type }\end{array}$ & $\begin{array}{l}\text { Sequencing } \\
\text { Technique }\end{array}$ & Modulatory Effect \\
\hline miR-146a $[94,97]$ & $\begin{array}{l}\text { Upregulated } \\
\text { in UM-patients }\end{array}$ & $\begin{array}{l}\text { EVs: vitreous, } \\
\text { plasma and FFPE } \\
\text { UM-Tissue; } \\
\text { Plasma }\end{array}$ & $\begin{array}{l}\text { TLDA/ } \\
\text { RT-PCR }\end{array}$ & \multirow{2}{*}{$\begin{array}{l}\text { MiR-146 has a potential immunosuppressive role, } \\
\text { when upregulated it causes NK-cell proliferation } \\
\text { inhibition and apoptosis induction [103]. Additionally, } \\
\text { miR-146 is regulated by microphtalmia-associated } \\
\text { transcription factor (MITF) [94]. }\end{array}$} \\
\hline miR-146a [97] & $\begin{array}{l}\text { Upregulated in } \\
\text { metastatic } \\
\text { patients }\end{array}$ & Plasma & RT-PCR & \\
\hline miR-155 [97] & $\begin{array}{l}\text { Upregulated } \\
\text { in metastatic } \\
\text { patients }\end{array}$ & Plasma & RT-PCR & \multirow{2}{*}{$\begin{array}{l}\text { Is upregulated in UM-tumors and promotes invasion } \\
\text { and proliferation by targeting Nedd4-family interactive } \\
\text { protein } 1 \text { (NDFIP1). NDFIP1 is necessary for } \\
\text { ubiquitination and translocation of, tumor suppressor, } \\
\text { PTEN [116-118]. Upregulation is correlated to } \\
\text { monosomy } 3 \text { status [118]. }\end{array}$} \\
\hline miR-155 [94] & $\begin{array}{l}\text { Downregulated } \\
\text { in UM-patients }\end{array}$ & VH and VH EVs & TLDA & \\
\hline
\end{tabular}

\begin{tabular}{cccc}
\hline miR-181a [97] & $\begin{array}{c}\text { Downregulated } \\
\text { in metastatic } \\
\text { patients }\end{array}$ & Plasma & RT-PCR \\
\hline miR-181a [94] & $\begin{array}{c}\text { Downregulated } \\
\text { in UM-patients }\end{array}$ & VH and VH EVs & TLDA \\
\hline miR-181a [97] & $\begin{array}{c}\text { Upregulated in } \\
\text { UM-patients }\end{array}$ & Plasma & RT-PCR \\
\hline & & & \\
\hline
\end{tabular}

Upregulation inhibits CTD small phosphatase like (CTDSPL) expression, which in turn promotes cell cycle progression in UM cells [119].

$\begin{array}{ccc}\text { miR-210 [88] } & \begin{array}{c}\text { Upregulated } \\ \text { in UM-patients }\end{array} & \begin{array}{c}\text { EVs: isolated } \\ \text { liver } \\ \text { perfusate }\end{array}\end{array} \quad \mathrm{RT}^{2}$ array

Targets vascular endothelial growth factor (VEGF)-dependent endothelial cell migration and tube formation factor ephrin A3 and subsequently promotes angiogenesis by formation of capillary like structures [120] and is induced by hypoxia in melanoma [121].

\begin{tabular}{|c|c|c|c|c|}
\hline miR-223 [98] & $\begin{array}{l}\text { Upregulated in } \\
\text { monosomy } 3\end{array}$ & Plasma & $\begin{array}{l}\text { RT-PCR/ } \\
\text { qNPA }\end{array}$ & \multirow{2}{*}{$\begin{array}{l}\text { Regulates and suppresses myeloid derived suppressor } \\
\text { cells, which expand during pathology and are related } \\
\text { to UM [122-124]. }\end{array}$} \\
\hline miR-223 [97] & $\begin{array}{l}\text { Upregulated in } \\
\text { UM and } \\
\text { metastatic } \\
\text { patients }\end{array}$ & Plasma & RT-PCR & \\
\hline miR-320a [88] & $\begin{array}{c}\text { Upregulated } \\
\text { in UM-patients }\end{array}$ & $\begin{array}{l}\text { EVs: isolated } \\
\text { liver } \\
\text { perfusate }\end{array}$ & $\mathrm{RT}^{2}$ array & $\begin{array}{c}\text { Inhibits the epithelial to mesenchymal transition (EMT) } \\
\text { by regulating the transforming growth factor } \\
\text { (TGF)- } \beta 1 / \text { suppressor of mothers against } \\
\text { decapentaplegic (SMAD) pathway }[125,126] .\end{array}$ \\
\hline miR-370 [88] & $\begin{array}{c}\text { Upregulated } \\
\text { in UM-patients }\end{array}$ & $\begin{array}{l}\text { EVs: isolated } \\
\text { liver } \\
\text { perfusate }\end{array}$ & $\mathrm{RT}^{2}$ array & $\begin{array}{l}\text { Overexpression promotes cell growth and invasion of } \\
\text { melanoma cells by regulation of pyruvate } \\
\text { dehydrogenase E1 subunit Beta (PDHB) [127]. }\end{array}$ \\
\hline miR-486a-5p [88] & $\begin{array}{c}\text { Upregulated } \\
\text { in UM-patients }\end{array}$ & $\begin{array}{l}\text { EVs: isolated } \\
\text { liver } \\
\text { perfusate }\end{array}$ & $\mathrm{RT}^{2}$ array & $\begin{array}{l}\text { Overexpression inhibits proliferation and migration in } \\
\text { hepatocellular [128] and colorectal cancer [129]; } \\
\text { however, no mechanistic information is available for } \\
\text { (U)M. }\end{array}$ \\
\hline
\end{tabular}




\subsection{Proteins}

In 2007, Pardo et al. suggested proteomics for biomarker discovery. Using mass spectrometry they saw a higher abundance of melanoma-specific gp100 and Cathepsin $\mathrm{D}$ in sera from UM-patients compared to healthy individuals $[130,131]$. Ultimately, when looking for prognostic biomarkers retrieved from peripheral blood for prognostication, a distinction should be made between high and low risk of metastases.

Angi et al. found 15 proteins upregulated in the secreted proteins of high-risk UM-patients, among which were neurosecretory protein VGF, protein $\mathrm{V}$ homolog $(\mathrm{V})$, thrombospondin-2 (THBS2), neuropilin-2 (NRP2), peptidyl-glycine alpha-amidating monooxygenase (PAM), serine protease HTRA1 (HTRA1), plasminogen activator inhibitor 1 (SERPINE1), Laminin subunit alpha-1 (LAMA1), connective tissue growth factor (CTGF), extracellular matrix protein 1 (ECM1), and Insulin-like growth factor-binding protein 7 (IGFBP1) [132]. Moreover, these highly upregulated proteins of presumed exosomal origin are involved in extracellular matrix remodeling and cancer cell migration and invasion [132,133].

Protein abundance can be used for monitoring disease progression; soluble c-Met correlates to metastatic disease in cell lines, xenograft mice, and peripheral blood of UMpatients [134]. Another protein that is reported to be overexpressed in peripheral blood of patients harboring metastatic UM is Parkinson disease protein 7 (DJ-1), which has a potential anti-apoptotic function [135]. Additionally, elevated levels of osteopontin, S100 calcium binding protein beta (S-100 $\beta$ ), and melanoma inhibitory activity (MIA) have been reported in metastatic UM. Multiplexed analysis combining these three proteins results in high sensitivity and specificity (area under the curve $=0.91$ ) for the detection of hepatic metastases [136].

More recently, a multiplex assay of heat shock protein 27 and Osteopontin can accurately differentiate between metastatic and non-metastastatic UM after initial treatment [137]. Strikingly, no overlap is seen in proteins upregulated in metastatic UM between the different studies.

\subsection{Metabolites}

Tumor metabolomics has been performed for several years, which show an upregulated energy metabolism by utilizing the oxidative phosphorylation (OXPHOS) and succinate dehydrogenase (SDHA) pathways in UM [138,139]. However, these studies have been performed on tumor tissue and are not useful for minimally invasive prognostication yet.

Recent advances in machine learning opens opportunities for metabolic pattern recognition in peripheral blood samples. As a result, indirect tumor effects can be defined and these patterns can be recognized, as shown by Huang et al. for lung adenocarcinoma [140]. No such metabolomic profiles have been retrieved from peripheral blood of UM-patients but as for lung cancer, the detection of these in serum samples might hold prognostic value in the future.

\subsection{Hepatic Biomarkers}

Historically, hepatic biomarkers are used for monitoring metastasis formation to the most commonly affected organ [23]. Especially higher serum gamma glutamyl transferase $(\gamma \mathrm{GT})$ and serum lactate dehydrogenase (LDH) levels are correlated to metastases [141]. However, standard surveillance: physical examination, abdominal ultrasonography (US), chest X-rays, and liver function tests are not adequate for early detection of metastases [142,143]. Moreover, no prognostic information can be ascertained from the liver function tests at this point.

\section{Prognostic and Clinical Use of Medical Imaging}

Medical imaging plays a fundamental role in the initial screening, staging, and diagnosing of UM [13]. Currently, the diagnostic procedure entails clinical examination with slit lamp and indirect ophthalmoscopy and US. To objectify tumor thickness, orange pigment and subretinal fluid easier optical coherence tomography (OCT) and fundus 
autofluorescence imaging can be performed [144]. For visualizing the intrinsic tumor vasculature, fluorescein angiography and indocyanine green can be used [145]. However, at this moment of time these modalities do not offer added prognostic information.

After initial staging, the gold standard for metastasis surveillance is imaging, common laboratory tests and liver function tests [7]. It is common practice to screen UM-patients every 6-12 months by abdominal imaging, depending on tumor risk stratification [13]. Initial staging can be performed by (in ascending order based on resolution, cost, and patient burden): US, CT, MRI, or positron emission tomography/CT (PET/CT).

\subsection{Ultrasonography}

Conventional A- (amplitude, one dimensional) and B- (brightness, two dimensional) scans use ultrasonic waves to distinguish between tissue types through differences in density and elasticity. As such, a tumor can be detected by different uptake and reflection of these sound waves compared to healthy tissue [146]. US shows a typical homogenous gray pattern. The amplitude of an A-scan could be used to differentiate between cell types in the tumor; however, it cannot be used for reliable subclassification in UM. US can provide easy visualization of the tumor, without much burden for the patient. Therefore, it can easily be used for follow-up of the primary tumor when the eye is preserved after treatment.

In 2004, Coleman et al. reported an estimated prospective performance of $80.1 \%$ when they used ultrasound to evaluate extracellular matrix loops by backscatter analysis [146]. These extracellular matrix loops in the tumor, either individual or network forming loops, are correlated to a worse prognosis $[13,147]$.

\subsection{Optical Coherence Tomography}

OCT can be used primarily for retinal assessment by providing cross-sectional images based on optical backscatter patterns $[148,149]$. In recent years, advances have been made. The addition of enhanced depth imaging (EDI) makes a deeper visualization of the choroid possible [150]. Blood vessels can be visualized by computationally measuring blood flow, thus removing the need for an intravenously administered fluorescent dye [151].

Using OCT, EDI, and OCT-angiography; the tumor and its vasculature can be visualized and can help differentiate between melanoma and other tumors. Especially by observing a highly irregular and dense vasculature in the outer retinal layer and choroid capillary layers $[150,152]$. Furthermore, Li et al. observed a widening of the deep foveal avascular zone, and the capillary vessel density of both deep and superficial vessels was reduced [153].

Swept-source OCT uses a longer wavelength laser, which allows for increased penetrance and deeper imaging. Therefore, it could be used as a non-invasive diagnostic tool to differentiate between UM and naevi, as choroidal vessels are deeper in UM [154]. However, Pellegrini et al. performed swept-source OCT angiography and visualization was difficult due to pigmentation and subretinal fluid, both present in most UM cases [155].

Some differences in OCT images are documented between naevi and UM. Besides initial examination of the primary tumor, OCT could be used as a means for followup of the primary tumor in small and shallow UM. Above all, due to its ease of use and widespread availability. Unfortunately, no prognostic information for UM can be ascertained using OCT.

\subsection{Magnetic Resonance Imaging}

MRI is not part of standard imaging of the primary tumor. This is mainly due to practicality and historic difficulties in the duration of imaging (the eye needs to be completely still during MRI), and spatial resolution combined with artefacts caused by the air-to-bone border [156,157]. Although it is difficult to circumscribe flat shaped tumors using MRI, it can be used for assessing the tumor volume and visualizing extraocular spread [158], which are both independent prognostic factors for PFS and OS [13]. Ferreira et al. described extrascleral extension using MRI in three cases, which were later confirmed histopatho- 
logically or visually during surgery. Using MRI, one case of extrascleral extension was missed. They were also able to determine nerve sheet invasion, which was confirmed by the ophthalmic pathologist [147].

Recent studies have explored the prognostic capabilities of MRI in UM [147,156-159]. Diffusion-weighted (DW) MRI differentiates between tissue cellularity by evaluating water diffusion. The quantitative value of DW imaging, the apparent diffusion coefficient (ADC), can be used to assess therapy-induced regression of the tumor [159]. US is the gold standard for local tumor staging and surveillance and usually tumor regression is evaluated by US [13]. When ADC is measured, the treatment response can be detected earlier, as the tumor volume, which is used for US follow-up, decreases slowly after irradiation. Furthermore, in tumors with a low ADC irradiation tends to perform better than in high ADC tumors [158,159], which could be used in determining the best treatment strategy in the future. ADC is inversely correlated to tumor prominence [147], which could also be obtained by conventional imaging. Therefore, at present ADC does not add prognostic information.

Dynamic contrast-enhanced MRI (DCE-MRI) can visualize the microvascular blood flow of the tumor by monitoring the response of tissue on a paramagnetic contrast agent [160]. Wei et al. have shown a significant decrease in $\mathrm{K}^{\text {trans }}$, a measure for capillary permeability, in metastatic UM. These results suggest that tumors capable of metastasizing produce more but low-quality vessels in the tumor. Ultimately, DCE-MRI could possibly be of added prognostic value [157]. Overall, MRI could provide information previously only obtainable by histopathology.

\subsection{Computed Tomography}

\subsubsection{Computed Tomography}

CT generates cross-sectional images using Röntgen radiation, possibly combined with contrast agent. CT-scans are frequently used for metastatic detection or confirmation, preceded by US and conventional hepatic biomarkers [161].

Hepatic metastases can arise as solitary or multiple lesions. A miliary metastatic pattern is also reported, which consists of numerous small metastases throughout the liver. The number of metastatic lesions seen on CT or MRI correlate to OS, with more metastases correlating to shorter OS and OS is comparable in patients who have a miliary metastatic pattern or more than 10 metastatic lesions [162]. However, Yavuzyigitoglu et al. reported that gene mutation status, the most important factor for survival, does not correlate with the metastatic pattern [162]. So far, CT is only used for metastatic detection and no prognostically important information is derived.

\subsubsection{Positron Emission Tomography/Computed Tomography}

$\mathrm{PET} / \mathrm{CT}$ visualizes the uptake of radiolabeled molecules by tumor cells. In $\mathrm{UM},{ }^{18} \mathrm{~F}-$ FDG is used for measuring metabolic activity of tumor cells, either in the primary tumor or metastases $[163,164]$.

Several studies show correlation of PET/CT uptake with prognostic variables; an increased uptake in tumor cells with chromosome 3 loss [163,164], increasing tumor size [163] and AJCC T-classification [163] are reported. Nonetheless, no association with chromosome 8q gain, another indicator for prognosis, has been reported [163].

For detection of metastases, FDG-PET/CT is not undisputed, as multiple studies show a lack of uptake in some of the metastatic lesions $[165,166]$.

\section{Clinical Relevance and Added Value of Combining Minimally Invasive Modalities}

The aforementioned modalities all have limited prognostic value and, when using a technique alone, the added value is currently often insufficient. In UM, the tumor burden is low and blood-based biomarkers are usually found in lower quantities compared to, for example, lung [55], breast [78,167], or prostate cancer [31,168,169]. Therefore, the use of 
CTCs, ctDNA, or other biomarkers is usually hampered in UM-patients. However, these biomarkers combined with imaging might provide enough prognostic information.

Conventional genetic and histopathologic features can estimate PFS with a concordance of \pm 0.8 [11]. By combining multiple noninvasive modalities, the same precision needs to be accomplished. An advantage is that multiple blood-based biomarkers can be extracted from a single tube; after centrifugation, blood is separated in layers, with ctDNA and metabolites remaining in the plasma layer and CTCs can be isolated from the white blood cell layer. Liquid biopsies can also be taken from aqueous and vitreous humor. However, these techniques are more invasive and harbor risk in respect to the eye and they were not discussed extensively in this review.

Circulating tumor cells possess genetic information from the primary tumor, which consists of DNA, RNA, miRNA, proteins, and metabolites. Obviously, valuable information that can be used for a better understanding in the metastatic process and can possibly provide new insights for novel therapeutic options. CTCs can be genotyped, phenotyped, and enumerated. Therefore, CTCs harbor a valuable opportunity for prognostication. Unfortunately, CTCs are laborious, expensive, and time-consuming to capture and analyze. Therefore, CTC analysis is best suited for initial prognostication. For disease monitoring, other techniques will be more suited.

For example, ctDNA-analyses can be cheaper, and are easier and faster. ctDNA levels can be eloquently analyzed. The downside of analyzing ctDNA levels by droplet digital PCR (ddPCR) is that the targeted mutation needs to be known and sequencing of CTCs could provide such data. Currently, when no tissue is available for mutational analysis, hotspot-mutations in primary driver genes and SF3B1 could still be analyzed using ddPCR. Afterwards, during follow-up visits, disease progression can be monitored faster and more accurate by using ddPCR than by conventional follow-up. Furthermore, when the amount of ctDNA is sufficient, CNV-profiles can be obtained using sWGS and provide additional minimally invasive prognostic information.

During initial staging, multiple imaging modalities are used. By adjusting these procedures, some prognostic information can be ascertained and in combination with liquid biopsies this could be of added value for stratification of high and low-risk patients. Furthermore, both medical imaging and computer science have progressed in recent years. These advancements make pattern recognition by machine learning nowadays a valid option to find new patterns and correlations between images and survival or metastatic risk.

Ultimately, more attention should be given to combining these techniques for clinically beneficial studies in the near future. Depending on the robustness of the minimally invasive diagnostic tools, one or more techniques could be used for prognostication and validation thereof.

Author Contributions: Writing-Original Draft Preparation, D.P.d.B., E.B. and E.K.; WritingReview \& Editing, D.P.d.B., A.B.B., R.M.V., N.M.v.P., D.P., R.O.B.d.K., N.C.N., E.S.G., A.d.K., E.B. and E.K.; Supervision, E.B. and E.K.; Funding Acquisition, D.P.d.B., E.B., A.d.K. and E.K. All authors have read and agreed to the published version of the manuscript.

Funding: This research was funded by KWF (grant number 6905), stichting Coolsingel (grant number 495) and the Bayer Ophthalmic Research award (BORA) (2021).

Institutional Review Board Statement: Not applicable.

Acknowledgments: The authors wish to thank Elise Krabbendam from the Erasmus MC Medical Library for developing and updating the search strategies.

Conflicts of Interest: The authors declare no conflict of interest. The sponsors had no role in the design, execution, interpretation, or writing of this review. 


\section{Abbreviations}

\begin{tabular}{|c|c|}
\hline A-scan & A-mode ultrasonography \\
\hline ABCB5 & ATP-binding cassette sub-family B member 5 \\
\hline ADC & Apparent diffusion coefficient \\
\hline AJCC & American Joint committee on cancer \\
\hline $\mathrm{AKT}$ & Protein kinase B \\
\hline ALIX & Programmed cell death 6-interacting protein \\
\hline B-scan & B-mode ultrasonography \\
\hline$B A P 1$ & BRCA1-associated protein \\
\hline $\mathrm{CD}$ & Cluster of differentiation \\
\hline cfDNA & Cell free DNA \\
\hline $\mathrm{CM}$ & Cutaneous melanoma \\
\hline CNV & Copy number variation \\
\hline $\mathrm{CT}$ & Computed tomography \\
\hline СТC & Circulating tumor cell \\
\hline ctDNA & Circulating tumor DNA \\
\hline CTDSPL & CTD small phosphatase like \\
\hline CTGF & Connective tissue growth factor \\
\hline CTLA-1 & cytotoxic T-lymphocyte-associated antigen 4 \\
\hline CYSLTR2 & Cysteinyl Leukotriene Receptor 2 \\
\hline DCE-MRI & Dynamic contrast-enhanced magnetic resonance imaging \\
\hline ddPCR & Droplet digital PCR \\
\hline DJ-1 & Parkinson disease protein 7 \\
\hline DNA & Deoxyribonucleic acid \\
\hline dsDNA & Double stranded DNA \\
\hline DW & Diffusion-weighted \\
\hline ECM1 & Extracellular matrix protein 1 \\
\hline EDI & Enhanced depth imaging \\
\hline EIF1AX & Eukaryotic translation initiation factor $1 \mathrm{~A}, \mathrm{X}$-linked \\
\hline EMT & Epithelial to mesenchymal transition \\
\hline EpCAM & Epithelial cell adhesion molecule \\
\hline EV & Extracellular vesicles \\
\hline FDA & Food and drug administration \\
\hline FDG & Fluorodeoxyglucose \\
\hline FFPE & Formalin-fixed paraffin-embedded \\
\hline FISH & Fluorescence in situ hybridization \\
\hline FNAB & Fine needle aspiration biopsy \\
\hline fSRT & Fractionated stereotactic radiotherapy \\
\hline GNA11 & G-protein $\alpha$ subunit 11 \\
\hline GNAQ & G-protein $\alpha$ subunit $Q$ \\
\hline Gp100 & Glycoprotein 100 \\
\hline HLA & Human leukocyte antigen \\
\hline HOXA11 & Homeobox 11 \\
\hline HTRA1 & Serine proteoase HTRA1 \\
\hline IFN- $\gamma$ & Interferon gamma \\
\hline IGFBP1 & Insulin-like growth factor-binding protein 7 \\
\hline IL & Interleukin \\
\hline LAMA1 & Laminin subunit alpha-1 \\
\hline LAMP1 & Lysosome-associated membrane glycoprotein 1 \\
\hline $\mathrm{LDH}$ & Lactate dehydrogenase \\
\hline MACS & Magnetic activated cell sorting \\
\hline MAGED1 & Melanoma-associated antigen D1 \\
\hline MAGED2 & Melanoma-associated antigen D2 \\
\hline MCAM & Melanoma cell adhesion molecule \\
\hline MCSP & Melanoma-associated chondroitin sulfate proteoglycan \\
\hline MIA & Melanoma inhibitory activity \\
\hline
\end{tabular}




\begin{tabular}{|c|c|}
\hline $\operatorname{miR}$ & MicroRNA \\
\hline miRNA & MicroRNA \\
\hline MITF & Microphthalmia-associated transcription factor \\
\hline MLANA & Melanoma antigen recognized by T-cells 1 \\
\hline MRI & Magnetic resonance imaging \\
\hline mRNA & Messenger RNA \\
\hline NCAM & Neural cell adhesion molecules \\
\hline NDFIP1 & Nedd4-family interactive protein 1 \\
\hline NHS & National Health Service \\
\hline NRP2 & Neuropilin-2 \\
\hline OCT & Optical coherence tomography \\
\hline OS & Overall survival \\
\hline OXPHOS & Oxidative phosphorylation \\
\hline PAM & Peptidyl-glycine alpha-amidating monooxygenase \\
\hline PBT & proton beam therapy \\
\hline PD-1 & Programmed cell death protein 1 \\
\hline PDHB & Pyruvate dehydrogenase E1 subunit Beta \\
\hline PDT & photodynamic therapy \\
\hline $\mathrm{PET} / \mathrm{CT}$ & Positron emission tomography/computed tomography \\
\hline PFS & Progression free survival \\
\hline PI3K & Phosphoinositide 3-kinase \\
\hline PLCB4 & Phospholipase $\mathrm{C}$ beta 4 \\
\hline PTEN & Phosphatase and Tensin homolog \\
\hline qNPA & Quantitative nuclease protection assay \\
\hline RNA & Ribonucleic acid \\
\hline ROMS & Rotterdam Ocular Melanoma Study group \\
\hline RT-PCR & Reverse transcription polymerase chain reaction \\
\hline RT2-array & Qiagen RT2 miRNA PCR array (brain cancer panel) \\
\hline S-100ß & S100 calcium binding protein beta \\
\hline SDHA & Succinate dehydrogenase \\
\hline SERPINE1 & Plasminogen activator inhibitor, type 1 \\
\hline SF3B1 & Splicing factor $3 \mathrm{~B}$ unit 1 \\
\hline SMART-seq & Switching Mechanism at $5^{\prime}$ end of RNA Template \\
\hline sWGS & Shallow whole genome sequencing \\
\hline THBS2 & Thrombospondin 2 \\
\hline TLDA & Taqman low density array \\
\hline TOP2A & DNA topoisomerase IIa \\
\hline TTT & Transpupillary thermotherapy \\
\hline UK & United Kingdom \\
\hline ULBP2 & UL16-binding protein 2 \\
\hline UM & Uveal melanoma \\
\hline US & Ultrasonography \\
\hline $\mathrm{V}$ & Protein V homolog \\
\hline VA & Visual acuity \\
\hline VEGF & Vascular endothelial growth factor \\
\hline VGF & VGF nerve growth factor inducible \\
\hline $\mathrm{VH}$ & Vitreous humor \\
\hline$\gamma \mathrm{GT}$ & Gamma glutamyl transferase \\
\hline
\end{tabular}

\section{References}

1. Smidt-Nielsen, I.; Bagger, M.; Heegaard, S.; Andersen, K.K.; Kiilgaard, J.F. Posterior uveal melanoma incidence and survival by AJCC tumour size in a 70-year nationwide cohort. Acta Ophthalmol. 2021, 99, 1474-1482. [CrossRef] [PubMed]

2. Williams, B.K.; Di Nicola, M. Ocular Oncology_Primary and Metastatic Malignancies. Med. Clin. N. Am. 2021, 105, 531-550. [CrossRef] [PubMed]

3. Amaro, A.; Gangemi, R.; Piaggio, F.; Angelini, G.; Barisione, G.; Ferrini, S.; Pfeffer, U. The biology of uveal melanoma. Cancer Metastasis Rev. 2017, 36, 109-140. [CrossRef] [PubMed]

4. Smit, K.N.; Jager, M.J.; de Klein, A.; Kiliç, E. Uveal melanoma: Towards a molecular understanding. Prog. Retin. Eye Res. 2020, 75, 100800. [CrossRef] 
5. Bol, K.F.; Van den Bosch, T.; Schreibelt, G.; Mensink, H.W.; Keunen, J.E.; Kiliç, E.; Japing, W.J.; Geul, K.W.; Westdorp, H.; Boudewijns, S. Adjuvant dendritic cell vaccination in high-risk uveal melanoma. Ophthalmology 2016, 123, 2265-2267. [CrossRef]

6. Ramos-Casals, M.; Brahmer, J.R.; Callahan, M.K.; Flores-Chávez, A.; Keegan, N.; Khamashta, M.A.; Lambotte, O.; Mariette, X.; Prat, A.; Suárez-Almazor, M.E. Immune-related adverse events of checkpoint inhibitors. Nat. Rev. Dis Prim. 2020, 6, 38. [CrossRef]

7. Pelster, M.S.; Gruschkus, S.K.; Bassett, R.; Gombos, D.S.; Shephard, M.; Posada, L.; Glover, M.S.; Simien, R.; Diab, A.; Hwu, P. Nivolumab and ipilimumab in metastatic uveal melanoma: Results from a single-arm phase II study. J. Clin. Oncol. 2021, 39, 599-607. [CrossRef]

8. Hoefsmit, E.P.; Rozeman, E.A.; Van, T.M.; Dimitriadis, P.; Krijgsman, O.; Conway, J.W.; da Silva, I.P.; van der Wal, J.E.; Ketelaars, S.L.; Bresser, K. Comprehensive analysis of cutaneous and uveal melanoma liver metastases. J. Immunother. Cancer 2020, 8 , e001501. [CrossRef]

9. Nathan, P.; Hassel, J.C.; Rutkowski, P.; Baurain, J.-F.; Butler, M.O.; Schlaak, M.; Sullivan, R.J.; Ochsenreither, S.; Dummer, R.; Kirkwood, J.M. Overall Survival Benefit with Tebentafusp in Metastatic Uveal Melanoma. N. Engl. J. Med. 2021, 385, 1196-1206. [CrossRef]

10. Vichitvejpaisal, P.; Dalvin, L.A.; Mazloumi, M.; Ewens, K.G.; Ganguly, A.; Shields, C.L. Genetic analysis of uveal melanoma in 658 patients using the cancer genome atlas classification of uveal melanoma as A, B, C, and D. Ophthalmology 2019, 126, 1445-1453. [CrossRef]

11. Drabarek, W.; Yavuzyigitoglu, S.; Obulkasim, A.; van Riet, J.; Smit, K.N.; van Poppelen, N.M.; Vaarwater, J.; Brands, T.; Eussen, B.; Verdijk, R.M. Multi-modality analysis improves survival prediction in enucleated uveal melanoma patients. Investig. Ophthalmol. Vis. Sci. 2019, 60, 3595-3605. [CrossRef] [PubMed]

12. Yavuzyigitoglu, S.; Koopmans, A.E.; Verdijk, R.M.; Vaarwater, J.; Eussen, B.; Van Bodegom, A.; Paridaens, D.; Kiliç, E.; de Klein, A.; Group, R.O.M.S. Uveal melanomas with SF3B1 mutations: A distinct subclass associated with late-onset metastases. Ophthalmology 2016, 123, 1118-1128. [CrossRef] [PubMed]

13. Kivelä, T.; Simpson, R.; Grossniklaus, H.E.; Jager, M.J.; Singh, A.D.; Caminal, J.M.; Pavlick, A.C.; Kujala, E.; Coupland, S.E.; Finger, P.T. Uveal Melanoma. In AJCC Cancer Staging Manual; Amin, M.B., Edge, S.B., Greene, F.L., Byrd, D.R., Brookland, R.K., Washington, M.K., Gershenwald, J.E., Compton, C.C., Hess, K.R., Sullivan, D.C., et al., Eds.; Springer International Publishing: Berlin/Heidelberg, Germany, 2017; Volume 8, pp. 805-831.

14. Robertson, A.G.; Shih, J.; Yau, C.; Gibb, E.A.; Oba, J. Integrative analysis identifies four molecular and clinical subsets in uveal melanoma. Cancer Cell 2017, 23, 204-220.e215. [CrossRef] [PubMed]

15. Shields, C.L.; Kaliki, S.; Furuta, M.; Mashayekhi, A.; Shields, J.A. Clinical spectrum and prognosis of uveal melanoma based on age at presentation in 8,033 cases. Retina 2012, 32, 1363-1372. [CrossRef]

16. Bagger, M.; Smidt-Nielsen, I.; Andersen, M.K.; Jensen, P.K.; Heegaard, S.; Andersen, K.K.; Friis, S.; Kiilgaard, J.F. Long-term metastatic risk after biopsy of posterior uveal melanoma. Ophthalmology 2018, 125, 1969-1976. [CrossRef]

17. Caminal, J.M.; Sanz, S.; Carreras, M.; Català, I.; Arruga, J.; Roca, G. Epibulbar seeding at the site of a transvitreal fine-needle aspiration biopsy. Arch. Ophthalmol. 2006, 124, 587-589. [CrossRef]

18. Schefler, A.C.; Gologorsky, D.; Marr, B.P.; Shields, C.L.; Zeolite, I.; Abramson, D.H. Extraocular extension of uveal melanoma after fine-needle aspiration, vitrectomy, and open biopsy. JAMA Ophthalmol. 2013, 131, 1220-1224. [CrossRef]

19. Wilham, J. Fine Needle Aspiration Biopsy with Adjunct i Immunohistochemistry in Intraocular Tumor Management. Acta Cytol. 2005, 49, 297-308

20. Cohen, V.; Dinakaran, S.; Parsons, M.; Rennie, I. Transvitreal fine needle aspiration biopsy: The influence of intraocular lesion size on diagnostic biopsy result. Eye 2001, 15, 143-147. [CrossRef]

21. Singh, A.D.; Medina, C.A.; Singh, N.; Aronow, M.E.; Biscotti, C.V.; Triozzi, P.L. Fine-needle aspiration biopsy of uveal melanoma: Outcomes and complications. Br. J. Ophthalmol. 2016, 100, 456-462. [CrossRef]

22. Bagger, M.; Tebering, J.F.; Kiilgaard, J.F. The ocular consequences and applicability of minimally invasive 25-gauge transvitreal retinochoroidal biopsy. Ophthalmology 2013, 120, 2565-2572. [CrossRef] [PubMed]

23. Eleuteri, A.; Rola, A.C.; Kalirai, H.; Hussain, R.; Sacco, J.; Damato, B.E.; Heimann, H.; Coupland, S.E.; Taktak, A.F. Cost-utility analysis of a decade of liver screening for metastases using the Liverpool Uveal Melanoma Prognosticator Online (LUMPO) Comput. Biol. Med. 2021, 130, 104221. [CrossRef] [PubMed]

24. Anand, K.; Roszik, J.; Gombos, D.; Upshaw, J.; Sarli, V.; Meas, S.; Lucci, A.; Hall, C.; Patel, S. Pilot study of circulating tumor cells in early-stage and metastatic uveal melanoma. Cancers 2019, 11, 856. [CrossRef] [PubMed]

25. Mouliere, F.; Chandrananda, D.; Piskorz, A.M.; Moore, E.K.; Morris, J.; Ahlborn, L.B.; Mair, R.; Goranova, T.; Marass, F.; Heider, K. Enhanced detection of circulating tumor DNA by fragment size analysis. Sci. Transl. Med. 2018, 10, eaat492. [CrossRef]

26. Beasley, A.; Isaacs, T.; Khattak, M.A.; Freeman, J.B.; Allcock, R.; Chen, F.K.; Pereira, M.R.; Yau, K.; Bentel, J.; Vermeulen, T.; et al. Clinical application of circulating tumor cells and circulating tumor DNA in uveal melanoma. JCO Precis. Oncol. 2018, 2, 1-12. [CrossRef]

27. Wisser, D.; van Ackern, K.; Knoll, E.; Wisser, H.; Bertsch, T. Blood loss from laboratory tests. Clin. Chem. 2003, 49, 1651-1655. [CrossRef]

28. Aceto, N.; Bardia, A.; Miyamoto, D.T.; Donaldson, M.C.; Wittner, B.S.; Spencer, J.A.; Yu, M.; Pely, A.; Engstrom, A.; Zhu, H. Circulating tumor cell clusters are oligoclonal precursors of breast cancer metastasis. Cell 2014, 158, 1110-1122. [CrossRef] 
29. Rao, C.; Bui, T.; Connelly, M.; Doyle, G.; Karydis, I.; Middleton, M.; Clack, G.; Malone, M.; Coumans, F.; Terstappen, L. Circulating melanoma cells and survival in metastatic melanoma. Int. J. Oncol. 2011, 38, 755-760.

30. Salvianti, F.; Pazzagli, M.; Pinzani, P. Single circulating tumor cell sequencing as an advanced tool in cancer management. Expert Rev. Mol. Diagn. 2016, 16, 51-63. [CrossRef]

31. Kozminsky, M.; Fouladdel, S.; Chung, J.S.; Wang, Y.; Smith, D.C.; Alva, A.; Azizi, E.; Morgan, T.; Nagrath, S. Detection of CTC clusters and a dedifferentiated RNA-expression survival signature in prostate cancer. Adv. Sci. 2019, 6, 1801254. [CrossRef]

32. Schuster, R.; Bechrakis, N.E.; Stroux, A.; Busse, A.; Schmittel, A.; Thiel, E.; Foerster, M.H.; Keilholz, U. Prognostic relevance of circulating tumor cells in metastatic uveal melanoma. Oncology 2011, 80, 57-62. [CrossRef] [PubMed]

33. Pantel, K.; Speicher, M. The biology of circulating tumor cells. Oncogene 2016, 35, 1216-1224. [CrossRef]

34. Tan, W.; Liang, G.; Xie, X.; Jiang, W.; Tan, L.; Sanders, A.J.; Liu, Z.; Ling, Y.; Zhong, W.; Tian, Z. Incorporating MicroRNA into molecular phenotypes of circulating tumor cells enhances the prognostic accuracy for patients with metastatic breast cancer. Oncologist 2019, 24, e1044. [CrossRef] [PubMed]

35. Abouleila, Y.; Onidani, K.; Ali, A.; Shoji, H.; Kawai, T.; Lim, C.T.; Kumar, V.; Okaya, S.; Kato, K.; Hiyama, E. Live single cell mass spectrometry reveals cancer-specific metabolic profiles of circulating tumor cells. Cancer Sci. 2019, 110, 697-706. [CrossRef]

36. Gkountela, S.; Castro-Giner, F.; Szczerba, B.M.; Vetter, M.; Landin, J.; Scherrer, R.; Krol, I.; Scheidmann, M.C.; Beisel, C.; Stirnimann, C.U. Circulating tumor cell clustering shapes DNA methylation to enable metastasis seeding. Cell 2019, 176, 98-112. [CrossRef]

37. Foss, A.J.E.; Guille, M.J.; Occleston, N.L.; Hykin, P.G.; Hungerford, J.L.; Lightman, S. The detection of melanoma cells in peripheral blood by reverse transcription-polymerase chain reaction. Br. J. Cancer 1995, 72, 155-159. [CrossRef]

38. Tobal, K.; Sherman, L.S.; Foss, A.J.E.; Lightman, S.L. Detection of melanocytes from uveal melanoma in peripheral blood using the polymerase chain reaction. Investig. Ophthalmol. Vis. Sci. 1993, 34, 2622-2625.

39. Bidard, F.C.; Madic, J.; Mariani, P.; Piperno-Neumann, S.; Rampanou, A.; Servois, V.; Cassoux, N.; Desjardins, L.; Milder, M.; Vaucher, I.; et al. Detection rate and prognostic value of circulating tumor cells and circulating tumor DNA in metastatic uveal melanoma. Int. J. Cancer 2014, 134, 1207-1213. [CrossRef]

40. Bande, M.F.; Santiago, M.; Muinelo-Romay, L.; Blanco, M.J.; Mera, P.; Capeans, C.; Pardo, M.; Piñeiro, A. Detection of circulating melanoma cells in choroidal melanocytic lesions. BMC Res. Notes 2015, 8, 452. [CrossRef]

41. Tura, A.; Lüke, J.; Merz, H.; Reinsberg, M.; Lüke, M.; Jager, M.J.; Grisanti, S. Identification of circulating melanoma cells in uveal melanoma patients by dual-marker immunoenrichment. Investig. Ophthalmol. Vis. Sci. 2014, 55, 4395-4404. [CrossRef]

42. Mazzini, C.; Pinzani, P.; Salvianti, F.; Scatena, C.; Paglierani, M.; Ucci, F.; Pazzagli, M.; Massi, D. Circulating tumor cells detection and counting in uveal melanomas by a filtration-based method. Cancers 2014, 6, 323-332. [CrossRef] [PubMed]

43. Nagrath, S.; Sequist, L.V.; Maheswaran, S.; Bell, D.W.; Irimia, D.; Ulkus, L.; Smith, M.R.; Kwak, E.L.; Digumarthy, S.; Muzikansky, A. Isolation of rare circulating tumour cells in cancer patients by microchip technology. Nature 2007, 450, 1235-1239. [CrossRef]

44. Uguen, A. Digital Pathology Slides-based Measurement of Tumor Cells and Lymphocytes Within Cytology Samples Supports the Relevance of the Separation by Size of Nonhematological Tumor and Hematological Nontumor Cells in Liquid Biopsies. Appl. Immunohistochem. Mol. Morphol. 2021, 29, 494-498. [CrossRef] [PubMed]

45. Huebner, H.; Fasching, P.A.; Gumbrecht, W.; Jud, S.; Rauh, C.; Matzas, M.; Paulicka, P.; Friedrich, K.; Lux, M.P.; Volz, B. Filtration based assessment of CTCs and CellSearch ${ }^{\circledR}$ based assessment are both powerful predictors of prognosis for metastatic breast cancer patients. BMC Cancer 2018, 18, 204. [CrossRef] [PubMed]

46. Tura, A.; Merz, H.; Reinsberg, M.; Lüke, M.; Jager, M.J.; Grisanti, S.; Lüke, J. Analysis of monosomy-3 in immunomagnetically isolated circulating melanoma cells in uveal melanoma patients. Pigment Cell Melanoma Res. 2016, 29, 583-589. [CrossRef] [PubMed]

47. Hoshino, K.; Huang, Y.-Y.; Lane, N.; Huebschman, M.; Uhr, J.W.; Frenkel, E.P.; Zhang, X. Microchip-based immunomagnetic detection of circulating tumor cells. Lab Chip 2011, 11, 3449-3457. [CrossRef] [PubMed]

48. Marques, G.S.; Silva, Z.; Videira, P.A. Antitumor efficacy of human monocyte-derived dendritic cells: Comparing effects of two monocyte isolation methods. Biol. Proced. Online 2018, 20, 4. [CrossRef]

49. Ulmer, A.; Beutel, J.; Süsskind, D.; Hilgers, R.D.; Ziemssen, F.; Lüke, M.; Röcken, M.; Rohrbach, M.; Fierlbeck, G.; Bartz-Schmidt, K.U.; et al. Visualization of circulating melanoma cells in peripheral blood of patients with primary uveal melanoma. Clin. Cancer Res. 2008, 14, 4469-4474. [CrossRef]

50. Suesskind, D.; Ulmer, A.; Schiebel, U.; Fierlbeck, G.; Spitzer, B.; Spitzer, M.S.; Bartz-Schmidt, K.U.; Grisanti, S. Circulating melanoma cells in peripheral blood of patients with uveal melanoma before and after different therapies and association with prognostic parameters: A pilot study. Acta Ophthalmol. 2011, 89, 17-24. [CrossRef]

51. Beasley, A.B.; Isaacs, T.W.; Vermeulen, T.; Freeman, J.; DeSousa, J.-L.; Bhikoo, R.; Hennessy, D.; Reid, A.; Chen, F.K.; Bentel, J.; et al. Analysis of Circulating Tumour Cells in Early-Stage Uveal Melanoma: Evaluation of Tumour Marker Expression to Increase Capture. Cancers 2021, 13, 5990. [CrossRef]

52. Cools-Lartigue, J.J.; McCauley, C.S.; Marshall, J.-C.A.; Di Cesare, S.; Gregoire, F.; Antecka, E.; Logan, P.; Burnier, M.N., Jr. Immunomagnetic isolation and in vitro expansion of human uveal melanoma cell lines. Mol. Vis. 2008, 14, 50. [PubMed]

53. Campos, M.; Prior, C.; Warleta, F.; Zudaire, I.; Ruiz-Mora, J.; Catena, R.; Calvo, A.; José, J.G. Phenotypic and genetic characterization of circulating tumor cells by combining immunomagnetic selection and FICTION techniques. J. Histochem. Cytochem. 2008, 56, 667-675. [CrossRef] [PubMed] 
54. Brase, J.C.; Schmidt, M.; Fischbach, T.; Sültmann, H.; Bojar, H.; Koelbl, H.; Hellwig, B.; Rahnenführer, J.; Hengstler, J.G.; Gehrmann, M.C. ERBB2 and TOP2A in breast cancer: A comprehensive analysis of gene amplification, RNA levels, and protein expression and their influence on prognosis and prediction. Clin. Cancer Res. 2010, 16, 2391-2401. [CrossRef] [PubMed]

55. Su, Z.; Wang, Z.; Ni, X.; Duan, J.; Gao, Y.; Zhuo, M.; Li, R.; Zhao, J.; Ma, Q.; Bai, H. Inferring the evolution and progression of small-cell lung cancer by single-cell sequencing of circulating tumor cells. Clin. Cancer Res. 2019, 25, 5049-5060. [CrossRef]

56. Zong, C.; Lu, S.; Chapman, A.R.; Xie, X.S. Genome-wide detection of single-nucleotide and copy-number variations of a single human cell. Science 2012, 338, 1622-1626. [CrossRef]

57. De Luca, G.; Cardinali, B.; Del Mastro, L.; Lastraioli, S.; Carli, F.; Ferrarini, M.; Calin, G.A.; Garuti, A.; Mazzitelli, C.; Zupo, S. Optimization of a WGA-Free Molecular Tagging-Based NGS Protocol for CTCs Mutational Profiling. Int. J. Mol. Sci. 2020, 21, 4364. [CrossRef]

58. Ramsköld, D.; Luo, S.; Wang, Y.-C.; Li, R.; Deng, Q.; Faridani, O.R.; Daniels, G.A.; Khrebtukova, I.; Loring, J.F.; Laurent, L.C. Full-length mRNA-Seq from single-cell levels of RNA and individual circulating tumor cells. Nat. Biotechnol. 2012, 30, 777-782. [CrossRef]

59. Shi, F.; Jia, F.; Wei, Z.; Ma, Y.; Fang, Z.; Zhang, W.; Hu, Z. A Microfluidic Chip for Efficient Circulating Tumor Cells Enrichment, Screening, and Single-Cell RNA Sequencing. Proteomics 2021, 21, 2000060. [CrossRef]

60. Lang, J.E.; Ring, A.; Porras, T.; Kaur, P.; Forte, V.A.; Mineyev, N.; Tripathy, D.; Press, M.F.; Campo, D. RNA-Seq of circulating tumor cells in stage II-III breast cancer. Ann. Surg. Oncol. 2018, 25, 2261-2270. [CrossRef]

61. Schwarzenbach, H.; Hoon, D.S.; Pantel, K. Cell-free nucleic acids as biomarkers in cancer patients. Nat. Rev. Cancer 2011, 11, 426-437. [CrossRef]

62. Alborelli, I.; Generali, D.; Jermann, P.; Cappelletti, M.R.; Ferrero, G.; Scaggiante, B.; Bortul, M.; Zanconati, F.; Nicolet, S.; Haegele, J. Cell-free DNA analysis in healthy individuals by next-generation sequencing: A proof of concept and technical validation study. Cell Death Dis. 2019, 10, 534. [CrossRef] [PubMed]

63. Swarup, V.; Rajeswari, M. Circulating (cell-free) nucleic acids-A promising, non-invasive tool for early detection of several human diseases. FEBS Lett. 2007, 581, 795-799. [CrossRef] [PubMed]

64. Valle-Inclan, J.E.; Stangl, C.; de Jong, A.C.; van Dessel, L.F.; van Roosmalen, M.J.; Helmijr, J.C.; Renkens, I.; Janssen, R.; de Blank, S.; de Witte, C.J.; et al. Optimizing Nanopore sequencing-based detection of structural variants enables individualized circulating tumor DNA-based disease monitoring in cancer patients. Genome Med. 2021, 13, 86. [CrossRef] [PubMed]

65. Diehl, F.; Schmidt, K.; Choti, M.A.; Romans, K.; Goodman, S.; Li, M.; Thornton, K.; Agrawal, N.; Sokoll, L.; Szabo, S.A. Circulating mutant DNA to assess tumor dynamics. Nat. Med. 2008, 14, 985-990. [CrossRef]

66. Siravegna, G.; Marsoni, S.; Siena, S.; Bardelli, A. Integrating liquid biopsies into the management of cancer. Nat. Rev. Clin. Oncol. 2017, 14, 531-548. [CrossRef] [PubMed]

67. Alcaide, M.; Cheung, M.; Hillman, J.; Rassekh, S.R.; Deyell, R.J.; Batist, G.; Karsan, A.; Wyatt, A.W.; Johnson, N.; Scott, D.W. Evaluating the quantity, quality and size distribution of cell-free DNA by multiplex droplet digital PCR. Sci. Rep. 2020, 10, 12564. [CrossRef] [PubMed]

68. Volik, S.; Alcaide, M.; Morin, R.D.; Collins, C. Cell-free DNA (cfDNA): Clinical significance and utility in cancer shaped by emerging technologies. Mol. Cancer Res. 2016, 14, 898-908. [CrossRef]

69. Wang, X.; Wang, L.; Su, Y.; Yue, Z.; Xing, T.; Zhao, W.; Zhao, Q.; Duan, C.; Huang, C.; Zhang, D. Plasma cell-free DNA quantification is highly correlated to tumor burden in children with neuroblastoma. Cancer Med. 2018, 7, 3022-3030. [CrossRef]

70. Park, J.J.; Diefenbach, R.J.; Byrne, N.; Long, G.V.; Scolyer, R.A.; Gray, E.S.; Carlino, M.S.; Rizos, H. Circulating Tumor DNA Reflects Uveal Melanoma Responses to Protein Kinase C Inhibition. Cancers 2021, 13, 1740. [CrossRef]

71. Ma, J.; Weng, L.; Bastian, B.C.; Chen, X. Functional characterization of uveal melanoma oncogenes. Oncogene 2021, 40, 806-820. [CrossRef]

72. Cabel, L.; Riva, F.; Servois, V.; Livartowski, A.; Daniel, C.; Rampanou, A.; Lantz, O.; Romano, E.; Milder, M.; Buecher, B.; et al Circulating tumor DNA changes for early monitoring of anti-PD1 immunotherapy: A proof-of-concept study. Ann. Oncol. 2017, 28, 1996-2001. [CrossRef]

73. Nguyen, J.Q.N.; Drabarek, W.; Yavuzyigitoglu, S.; Medico Salsench, E.; Verdijk, R.M.; Naus, N.C.; de Klein, A.; Kiliç, E.; Brosens, E. Spliceosome Mutations in Uveal Melanoma. Int. J. Mol. Sci. 2020, 21, 9546. [CrossRef]

74. Shields, C.L.; Furuta, M.; Berman, E.L.; Zahler, J.D.; Hoberman, D.M.; Dinh, D.H.; Mashayekhi, A.; Shields, J.A. Choroidal nevus transformation into melanoma: Analysis of 2514 consecutive cases. Arch. Ophthalmol. 2009, 127, 981-987. [CrossRef]

75. Bustamante, P.; Tsering, T.; Coblentz, J.; Mastromonaco, C.; Abdouh, M.; Fonseca, C.; Proença, R.P.; Blanchard, N.; Dugé, C.L.; Andujar, R.A.S. Circulating tumor DNA tracking through driver mutations as a liquid biopsy-based biomarker for uveal melanoma. J. Exp. Clin. Cancer Res. 2021, 40, 196. [CrossRef]

76. Le Guin, C.H.; Bornfeld, N.; Bechrakis, N.E.; Jabbarli, L.; Richly, H.; Lohmann, D.R.; Zeschnigk, M. Early detection of metastatic uveal melanoma by the analysis of tumor-specific mutations in cell-free plasma DNA. Cancer Med. 2021, 10, 5974-5982. [CrossRef]

77. Peneder, P.; Stutz, A.M.; Surdez, D.; Krumbholz, M.; Semper, S.; Chicard, M.; Sheffield, N.C.; Pierron, G.; Lapouble, E.; Totzl, M.; et al. Multimodal analysis of cell-free DNA whole-genome sequencing for pediatric cancers with low mutational burden. Nat. Commun. 2021, 12, 3230. [CrossRef] 
78. Adalsteinsson, V.A.; Ha, G.; Freeman, S.S.; Choudhury, A.D.; Stover, D.G.; Parsons, H.A.; Gydush, G.; Reed, S.C.; Rotem, D.; Rhoades, J. Scalable whole-exome sequencing of cell-free DNA reveals high concordance with metastatic tumors. Nat. Commun. 2017, 8, 1324. [CrossRef]

79. Stover, D.G.; Parsons, H.A.; Ha, G.; Freeman, S.S.; Barry, W.T.; Guo, H.; Choudhury, A.D.; Gydush, G.; Reed, S.C.; Rhoades, J. Association of cell-free DNA tumor fraction and somatic copy number alterations with survival in metastatic triple-negative breast cancer. J. Clin. Oncol. 2018, 36, 543. [CrossRef]

80. Van Niel, G.; d'Angelo, G.; Raposo, G. Shedding light on the cell biology of extracellular vesicles. Nat. Rev. Mol. Cell Biol. 2018, 19, 213. [CrossRef]

81. Tricarico, C.; Clancy, J.; D'Souza-Schorey, C. Biology and biogenesis of shed microvesicles. Small GTPases 2017, 8, $220-232$. [CrossRef]

82. Balaj, L.; Lessard, R.; Dai, L.; Cho, Y.-J.; Pomeroy, S.L.; Breakefield, X.O.; Skog, J. Tumour microvesicles contain retrotransposon elements and amplified oncogene sequences. Nat. Commun. 2011, 2, 180. [CrossRef]

83. Cocucci, E.; Racchetti, G.; Meldolesi, J. Shedding microvesicles: Artefacts no more. Trends Cell Biol. 2009, 19, 43-51. [CrossRef]

84. Tsering, T.; Laskaris, A.; Abdouh, M.; Bustamante, P.; Parent, S.; Jin, E.; Ferrier, S.T.; Arena, G.; Burnier, J.V. Uveal MelanomaDerived Extracellular Vesicles Display Transforming Potential and Carry Protein Cargo Involved in Metastatic Niche Preparation. Cancers 2020, 12, 2923. [CrossRef]

85. Thakur, B.K.; Zhang, H.; Becker, A.; Matei, I.; Huang, Y.; Costa-Silva, B.; Zheng, Y.; Hoshino, A.; Brazier, H.; Xiang, J. Doublestranded DNA in exosomes: A novel biomarker in cancer detection. Cell Res. 2014, 24, 766-769. [CrossRef]

86. Takahashi, A.; Okada, R.; Nagao, K.; Kawamata, Y.; Hanyu, A.; Yoshimoto, S.; Takasugi, M.; Watanabe, S.; Kanemaki, M.T.; Obuse, C. Exosomes maintain cellular homeostasis by excreting harmful DNA from cells. Nat. Commun. 2017, 8, 15287. [CrossRef]

87. Jeppesen, D.K.; Fenix, A.M.; Franklin, J.L.; Higginbotham, J.N.; Zhang, Q.; Zimmerman, L.J.; Liebler, D.C.; Ping, J.; Liu, Q.; Evans, R. Reassessment of exosome composition. Cell 2019, 177, 428-445.e418. [CrossRef]

88. Eldh, M.; Olofsson Bagge, R.; Lässer, C.; Svanvik, J.; Sjöstrand, M.; Mattsson, J.; Lindnér, P.; Choi, D.S.; Gho, Y.S.; Lötvall, J. MicroRNA in exosomes isolated directly from the liver circulation in patients with metastatic uveal melanoma. BMC Cancer 2014, 14, 962. [CrossRef]

89. Théry, C.; Witwer, K.W.; Aikawa, E.; Alcaraz, M.J.; Anderson, J.D.; Andriantsitohaina, R.; Antoniou, A.; Arab, T.; Archer, F.; Atkin-Smith, G.K. Minimal information for studies of extracellular vesicles 2018 (MISEV2018): A position statement of the International Society for Extracellular Vesicles and update of the MISEV2014 guidelines. J. Extracell. Vesicles 2018, 7, 1535750. [CrossRef]

90. An, M.; Wu, J.; Zhu, J.; Lubman, D.M. Comparison of an optimized ultracentrifugation method versus size-exclusion chromatography for isolation of exosomes from human serum. J. Proteome Res. 2018, 17, 3599-3605. [CrossRef]

91. Baranyai, T.; Herczeg, K.; Onódi, Z.; Voszka, I.; Módos, K.; Marton, N.; Nagy, G.; Mäger, I.; Wood, M.J.; El Andaloussi, S Isolation of exosomes from blood plasma: Qualitative and quantitative comparison of ultracentrifugation and size exclusion chromatography methods. PLoS ONE 2015, 10, e0145686. [CrossRef]

92. Wróblewska, J.P.; Lach, M.S.; Kulcenty, K.; Galus, Ł.; Suchorska, W.M.; Rösel, D.; Brábek, J.; Marszałek, A. The Analysis of Inflammation-Related Proteins in a Cargo of Exosomes Derived from the Serum of Uveal Melanoma Patients Reveals Potential Biomarkers of Disease Progression. Cancers 2021, 13, 3334. [CrossRef]

93. Iorio, M.V.; Croce, C.M. MicroRNAs in cancer: Small molecules with a huge impact. J. Clin. Oncol. 2009, 27, 5848. [CrossRef] [PubMed]

94. Ragusa, M.; Barbagallo, C.; Statello, L.; Caltabiano, R.; Russo, A.; Puzzo, L.; Avitabile, T.; Longo, A.; Toro, M.D.; Barbagallo, D.; et al. miRNA profiling in vitreous humor, vitreal exosomes and serum from uveal melanoma patients: Pathological and diagnostic implications. Cancer Biol. Ther. 2015, 16, 1387-1396. [CrossRef] [PubMed]

95. Madhavan, D.; Zucknick, M.; Wallwiener, M.; Cuk, K.; Modugno, C.; Scharpff, M.; Schott, S.; Heil, J.; Turchinovich, A.; Yang, R. Circulating miRNAs as surrogate markers for circulating tumor cells and prognostic markers in metastatic breast cancer. Clin. Cancer Res. 2012, 18, 5972-5982. [CrossRef]

96. Smit, K.N.; Chang, J.; Derks, K.; Vaarwater, J.; Brands, T.; Verdijk, R.M.; Wiemer, E.A.; Mensink, H.W.; Pothof, J.; de Klein, A. Aberrant MicroRNA expression and its implications for uveal melanoma metastasis. Cancers 2019, 11, 815. [CrossRef]

97. Achberger, S.; Aldrich, W.; Tubbs, R.; Crabb, J.W.; Singh, A.D.; Triozzi, P.L. Circulating immune cell and microRNA in patients with uveal melanoma developing metastatic disease. Mol. Immunol. 2014, 58, 182-186. [CrossRef]

98. Triozzi, P.L.; Achberger, S.; Aldrich, W.; Crabb, J.W.; Saunthararajah, Y.; Singh, A.D. Association of tumor and plasma microRNA expression with tumor monosomy-3 in patients with uveal melanoma. Clin. Epigenetics 2016, 8, 80. [CrossRef]

99. Chen, X.; Ba, Y.; Ma, L.; Cai, X.; Yin, Y.; Wang, K.; Guo, J.; Zhang, Y.; Chen, J.; Guo, X. Characterization of microRNAs in serum: A novel class of biomarkers for diagnosis of cancer and other diseases. Cell Res. 2008, 18, 997-1006. [CrossRef]

100. Gilad, S.; Meiri, E.; Yogev, Y.; Benjamin, S.; Lebanony, D.; Yerushalmi, N.; Benjamin, H.; Kushnir, M.; Cholakh, H.; Melamed, N. Serum microRNAs are promising novel biomarkers. PLoS ONE 2008, 3, e3148. [CrossRef]

101. Kosaka, N.; Iguchi, H.; Ochiya, T. Circulating microRNA in body fluid: A new potential biomarker for cancer diagnosis and prognosis. Cancer Sci. 2010, 101, 2087-2092. [CrossRef]

102. Kroh, E.M.; Parkin, R.K.; Mitchell, P.S.; Tewari, M. Analysis of circulating microRNA biomarkers in plasma and serum using quantitative reverse transcription-PCR (qRT-PCR). Methods 2010, 50, 298-301. [CrossRef] [PubMed] 
103. Aksenenko, M.; Palkina, N.; Komina, A.; Tashireva, L.; Ruksha, T. Differences in microRNA expression between melanoma and healthy adjacent skin. BMC Dermatol. 2019, 19, 1. [CrossRef] [PubMed]

104. He, W.; Cheng, Y. Inhibition of miR-20 promotes proliferation and autophagy in articular chondrocytes by PI3K/AKT/mTOR signaling pathway. Biomed. Pharmacother. 2018, 97, 607-615. [CrossRef]

105. White, N.M.; Fatoohi, E.; Metias, M.; Jung, K.; Stephan, C.; Yousef, G.M. Metastamirs: A stepping stone towards improved cancer management. Nat. Rev. Clin. Oncol. 2011, 8, 75. [CrossRef]

106. Wang, Y.C.; Yang, X.; Wei, W.B.; Xu, X.L. Role of microRNA-21 in uveal melanoma cell invasion and metastasis by regulating p53 and its downstream protein. Int. J. Ophthalmol. 2018, 11, 1258-1268.

107. Saldanha, G.; Potter, L.; Lee, Y.S.; Watson, S.; Shendge, P.; Pringle, J.H. MicroRNA-21 expression and its pathogenetic significance in cutaneous melanoma. Melanoma Res. 2016, 26, 21-28. [CrossRef]

108. Wu, L.; Zhu, L.; Li, Y.; Zheng, Z.; Lin, X.; Yang, C. LncRNA MEG3 promotes melanoma growth, metastasis and formation through modulating miR-21/E-cadherin axis. Cancer Cell Int. 2020, 20, 12. [CrossRef]

109. Cortez, M.A.; Ivan, C.; Valdecanas, D.; Wang, X.; Peltier, H.J.; Ye, Y.; Araujo, L.; Carbone, D.P.; Shilo, K.; Giri, D.K. PDL1 Regulation by p53 via miR-34. J. Natl. Cancer Inst. 2016, 108, djv303. [CrossRef]

110. Heinemann, A.; Zhao, F.; Pechlivanis, S.; Eberle, J.; Steinle, A.; Diederichs, S.; Schadendorf, D.; Paschen, A. Tumor suppressive microRNAs miR-34a/c control cancer cell expression of ULBP2, a stress-induced ligand of the natural killer cell receptor NKG2D. Cancer Res. 2012, 72, 460-471. [CrossRef]

111. Zhuang, L.; Yang, Y.; Ma, X.; Han, B.; Wang, Z.; Zhao, Q.; Wu, L.; Qu, Z. MicroRNA-92b promotes hepatocellular carcinoma progression by targeting Smad7 and is mediated by long non-coding RNA XIST. Cell Death Dis. 2016, 7, e2203. [CrossRef]

112. Zhao, G.; Wei, Z.; Guo, Y. MicroRNA-107 is a novel tumor suppressor targeting POU3F2 in melanoma. Biol. Res. 2020, 53, 1. [CrossRef]

113. Lu, Q.; Zhao, N.; Zha, G.; Wang, H.; Tong, Q.; Xin, S. LncRNA HOXA11-AS exerts oncogenic functions by repressing p21 and miR-124 in uveal melanoma. DNA Cell Biol. 2017, 36, 837-844. [CrossRef]

114. Shen, C.; Hua, H.; Gu, L.; Cao, S.; Cai, H.; Yao, X.; Chen, X. miR-124 functions as a melanoma tumor suppressor by targeting RACK1. OncoTargets Ther. 2019, 12, 9975. [CrossRef]

115. Wang, T.; Li, W.; Yin, S.; Chen, W. MiR-125b acts as a tumor suppressor of melanoma by targeting NCAM. J. BU ON 2021, 26, 182-188.

116. Peng, J.; Liu, H.; Liu, C. MiR-155 promotes uveal melanoma cell proliferation and invasion by regulating NDFIP1 expression. Technol. Cancer Res. Treat. 2017, 16, 1160-1167. [CrossRef]

117. Howitt, J.; Low, L.-H.; Putz, U.; Doan, A.; Lackovic, J.; Goh, C.-P.; Gunnersen, J.; Silke, J.; Tan, S.-S. Ndfip1 represses cell proliferation by controlling Pten localization and signaling specificity. J. Mol. Cell. Biol. 2015, 7, 119-131. [CrossRef]

118. Souri, Z.; Wierenga, A.; Kiliç, E.; Brosens, E.; Böhringer, S.; Kroes, W.G.; Verdijk, R.M.; van Der Velden, P.A.; Luyten, G.P.; Jager, M.J. MiRNAs Correlate with HLA Expression in Uveal Melanoma: Both Up-and Downregulation Are Related to Monosomy 3. Cancers 2021, 13, 4020. [CrossRef]

119. Zhang, L.; He, X.; Li, F.; Pan, H.; Huang, X.; Wen, X.; Zhang, H.; Li, B.; Ge, S.; Xu, X. The miR-181 family promotes cell cycle by targeting CTDSPL, a phosphatase-like tumor suppressor in uveal melanoma. J. Exp. Clin. Cancer Res. 2018, 37, 15. [CrossRef]

120. Fasanaro, P.; D'Alessandra, Y.; Di Stefano, V.; Melchionna, R.; Romani, S.; Pompilio, G.; Capogrossi, M.C.; Martelli, F. MicroRNA210 modulates endothelial cell response to hypoxia and inhibits the receptor tyrosine kinase ligand Ephrin-A3. J. Biol. Chem. 2008, 283, 15878-15883. [CrossRef]

121. Walbrecq, G.; Lecha, O.; Gaigneaux, A.; Fougeras, M.R.; Philippidou, D.; Margue, C.; Tetsi Nomigni, M.; Bernardin, F.; Dittmar, G.; Behrmann, I. Hypoxia-induced adaptations of miRNomes and proteomes in melanoma cells and their secreted extracellular vesicles. Cancers 2020, 12, 692. [CrossRef]

122. Liu, Q.; Zhang, M.; Jiang, X.; Zhang, Z.; Dai, L.; Min, S.; Wu, X.; He, Q.; Liu, J.; Zhang, Y. miR-223 suppresses differentiation of tumor-induced CD11b+ Gr1+ myeloid-derived suppressor cells from bone marrow cells. Int. J. Cancer 2011, 129, $2662-2673$. [CrossRef] [PubMed]

123. Gabrilovich, D.I.; Nagaraj, S. Myeloid-derived suppressor cells as regulators of the immune system. Nat. Rev. Immunol. 2009, 9, 162-174. [CrossRef] [PubMed]

124. McKenna, K.C.; Beatty, K.M.; Bilonick, R.A.; Schoenfield, L.; Lathrop, K.L.; Singh, A.D. Activated CD11b+ CD15+ granulocytes increase in the blood of patients with uveal melanoma. Investig. Ophthalmol. Vis. Sci. 2009, 50, 4295-4303. [CrossRef] [PubMed]

125. Sugano, T.; Masuda, M.; Takeshita, F.; Motoi, N.; Hirozane, T.; Goto, N.; Kashimoto, S.; Uno, Y.; Moriyama, H.; Sawa, M. Pharmacological blockage of transforming growth factor- $\beta$ signalling by a Traf2-and Nck-interacting kinase inhibitor, NCB-0846. Br. J. Cancer 2021, 124, 228-236. [CrossRef] [PubMed]

126. Zhang, H.H.; Li, R.; Li, Y.J.; Yu, X.X.; Sun, Q.N.; Li, A.Y.; Kong, Y. eIF4E-related miR-320a and miR-340-5p inhibit endometrial carcinoma cell metastatic capability by preventing TGF- $\beta 1$-induced epithelial-mesenchymal transition. Oncol. Rep. 2020, 43, 447-460. [CrossRef]

127. Wei, S.; Ma, W. MiR-370 functions as oncogene in melanoma by direct targeting pyruvate dehydrogenase B. Biomed. Pharmacother. 2017, 90, 278-286. [CrossRef]

128. He, J.; Xiao, B.; Li, X.; He, Y.; Li, L.; Sun, Z. MiR-486-5p suppresses proliferation and migration of hepatocellular carcinoma cells through downregulation of the E3 ubiquitin ligase CBL. BioMed Res. Int. 2019, 2019, 2732057. [CrossRef] 
129. Pisano, A.; Griñan-Lison, C.; Farace, C.; Fiorito, G.; Fenu, G.; Jiménez, G.; Scognamillo, F.; Peña-Martin, J.; Naccarati, A.; Pröll, J. The inhibitory role of mir-486-5p on csc phenotype has diagnostic and prognostic potential in colorectal cancer. Cancers 2020, 12, 3432. [CrossRef]

130. Pardo, M.; García, Á.; Antrobus, R.; Blanco, M.J.; Dwek, R.A.; Zitzmann, N. Biomarker discovery from uveal melanoma secretomes: Identification of gp100 and cathepsin D in patient serum. J. Proteome Res. 2007, 6, 2802-2811. [CrossRef]

131. Bande, M.F.; Santiago, M.; Mera, P. ME20-S as a Potential Biomarker for the Evaluation of Uveal Melanoma. Investig. Ophthalmol. Vis. Sci. 2015, 12, 7007-7011. [CrossRef]

132. Angi, M.; Kalirai, H.; Prendergast, S.; Simpson, D.; Hammond, D.E.; Madigan, M.C.; Beynon, R.J.; Coupland, S.E. In-depth proteomic profiling of the uveal melanoma secretome. Oncotarget 2016, 7, 49623-49635. [CrossRef] [PubMed]

133. Gilkes, D.M.; Semenza, G.L.; Wirtz, D. Hypoxia and the extracellular matrix: Drivers of tumour metastasis. Nat. Rev. Cancer 2014, 14, 430-439. [CrossRef] [PubMed]

134. Barisione, G.; Fabbi, M.; Gino, A.; Queirolo, P.; Orgiano, L.; Spano, L.; Picasso, V.; Pfeffer, U.; Mosci, C.; Jager, M.J. Potential role of soluble c-Met as a new candidate biomarker of metastatic uveal melanoma. JAMA Ophthalmol. 2015, 133, 1013-1021. [CrossRef] [PubMed]

135. Chen, L.L.; Tian, J.J.; Su, L.; Jing, Y.; Zhang, S.C.; Zhang, H.X.; Wang, X.Q.; Zhu, C.B. DJ-1: A promising marker in metastatic uveal melanoma. J. Cancer Res. Clin. Oncol. 2015, 141, 315-321. [CrossRef]

136. Barak, V.; Frenkel, S.; Kalickman, I.; Maniotis, A.J.; Folberg, R.; Pe'er, J. Serum markers to detect metastatic uveal melanoma. Anticancer Res. 2007, 27, 1897-1900.

137. Song, J.; Merbs, S.L.; Sokoll, L.J. A multiplex immunoassay of serum biomarkers for the detection of uveal melanoma. Clin. Proteomics 2019, 16, 10. [CrossRef]

138. Chattopadhyay, C.; Oba, J.; Roszik, J.; Marszalek, J.R.; Chen, K.; Qi, Y.; Eterovic, K.; Gordon Robertson, A.; Burks, J.K.; McCannel, T.A.; et al. Elevated endogenous SDHA drives pathological metabolism in highly metastatic uveal melanoma. Investig. Ophthalmol. Vis. Sci. 2019, 60, 4187-4195. [CrossRef]

139. Han, A.; Purwin, T.J.; Bechtel, N.; Liao, C.; Chua, V.; Seifert, E.; Sato, T.; Schug, Z.T.; Speicher, D.W.; Harbour, J.W. BAP1 mutant uveal melanoma is stratified by metabolic phenotypes with distinct vulnerability to metabolic inhibitors. Oncogene 2021, 40, 618-632. [CrossRef]

140. Huang, L.; Wang, L.; Hu, X.; Chen, S.; Tao, Y.; Su, H.; Yang, J.; Xu, W.; Vedarethinam, V.; Wu, S. Machine learning of serum metabolic patterns encodes early-stage lung adenocarcinoma. Nat. Commun. 2020, 11, 3556. [CrossRef]

141. Lorenzo, D.; Piulats, J.M.; Ochoa, M.; Arias, L.; Gutiérrez, C.; Català, J.; Cobos, E.; Garcia-Bru, P.; Dias, B.; Padrón-Pérez, N. Clinical predictors of survival in metastatic uveal melanoma. Jpn. J. Ophthalmol. 2019, 63, 197-209. [CrossRef]

142. Diener-West, M.; Reynolds, S.M.; Agugliaro, D.J.; Caldwell, R.; Cumming, K.; Earle, J.D.; Green, D.L.; Hawkins, B.S.; Hayman, J.; Jaiyesimi, I. Screening for metastasis from choroidal melanoma: The collaborative ocular melanoma study group report 23. J. Clin. Oncol. 2004, 22, 2438-2444. [CrossRef] [PubMed]

143. Hicks, C.; Foss, A.J.; Hungerford, J.L. Predictive power of screening tests for metastasis in uveal melanoma. Eye 1998, 12, 945-948. [CrossRef] [PubMed]

144. Kivelä, T. Diagnosis of uveal melanoma. Dev. Ophthalmol. 2012, 49, 1-15. [PubMed]

145. Grisanti, S.; Tura, A. Uveal Melanoma. In Noncutaneous Melanoma; Scott, J.F., Gerstenblith, M.R., Eds.; Codon Publications: Brisbane, Australia, 2018; pp. 1-18.

146. Coleman, D.J.; Silverman, R.H.; Rondeau, M.J.; Boldt, H.C.; Lloyd, H.O.; Lizzi, F.L.; Weingeist, T.A.; Chen, X.; Vangveeravong, S.; Folberg, R. Noninvasive in vivo detection of prognostic indicators for high-risk uveal melanoma: Ultrasound parameter imaging. Ophthalmology 2004, 111, 558-564. [CrossRef] [PubMed]

147. Ferreira, T.A.; Jaarsma-Coes, M.G.; Marinkovic, M.; Verbist, B.; Verdijk, R.M.; Jager, M.J.; Luyten, G.P.; Beenakker, J.-W.M. MR imaging characteristics of uveal melanoma with histopathological validation. Neuroradiology 2022, 64, 171-184. [CrossRef]

148. Hee, M.R.; Izatt, J.A.; Swanson, E.A.; Huang, D.; Schuman, J.S.; Lin, C.P.; Puliafito, C.A.; Fujimoto, J.G. Optical coherence tomography of the human retina. Arch. Ophthalmol. 1995, 113, 325-332. [CrossRef]

149. Yeung, L.; Lima, V.C.; Garcia, P.; Landa, G.; Rosen, R.B. Correlation between spectral domain optical coherence tomography findings and fluorescein angiography patterns in diabetic macular edema. Ophthalmology 2009, 116, 1158-1167. [CrossRef]

150. Cennamo, G.; Romano, M.R.; Breve, M.; Velotti, N.; Reibaldi, M.; De Crecchio, G. Evaluation of choroidal tumors with optical coherence tomography: Enhanced depth imaging and OCT-angiography features. Eye 2017, 31, 906-915. [CrossRef]

151. Ishibazawa, A.; Nagaoka, T.; Takahashi, A.; Omae, T.; Tani, T.; Sogawa, K.; Yokota, H.; Yoshida, A. Optical coherence tomography angiography in diabetic retinopathy: A prospective pilot study. Am. J. Ophthalmol. 2015, 160, 35-44.e1. [CrossRef]

152. Ali, Z.C.; Gray, J.; Balaskas, K. Features of choroidal naevi on swept source optical coherence tomography angiography and structural reverse flow optical coherence tomography. Graefe Arch. Clin. Exp. Ophthalmol. 2018, 256, 1319-1323. [CrossRef]

153. Li, Y.; Say, E.A.; Ferenczy, S.; Agni, M.; Shields, C.L. Altered parafoveal microvasculature in treatment-naive choroidal melanoma eyes detected by optical coherence tomography angiography. Retina 2017, 37, 32-40. [CrossRef] [PubMed]

154. Greig, E.C.; Laver, N.V.; Mendonca, L.S.; Levine, E.S.; Baumal, C.R.; Waheed, N.K.; Duker, J.S. Swept-Source Optical Coherence Tomography Angiography in Small Choroidal Melanomas and Choroidal Nevi. Retina 2021, 41, 1182. [CrossRef] [PubMed]

155. Pellegrini, M.; Corvi, F.; Invernizzi, A.; Ravera, V.; Cereda, M.G.; Staurenghi, G. Swept-source optical coherence tomography angiography in choroidal melanoma: An analysis of 22 consecutive cases. Retina 2019, 39, 1510-1519. [CrossRef] [PubMed] 
156. Ferreira, T.A.; Grech Fonk, L.; Jaarsma-Coes, M.G.; van Haren, G.G.; Marinkovic, M.; Beenakker, J.-W.M. MRI of uveal melanoma. Cancers 2019, 11, 377. [CrossRef]

157. Wei, W.; Jia, G.; von Tengg-Kobligk, H.; Heverhagen, J.T.; Abdel-Rahman, M.; Wei, L.; Christoforidis, J.B.; Davidorf, F.; Knopp, M.V. Dynamic contrast-enhanced magnetic resonance imaging of ocular melanoma as a tool to predict metastatic potential. $J$. Comput. Assist. Tomogr. 2017, 41, 823-827. [CrossRef]

158. Foti, P.V.; Longo, A.; Reibaldi, M.; Russo, A.; Privitera, G.; Spatola, C.; Raffaele, L.; Salamone, V.; Farina, R.; Palmucci, S. Uveal melanoma: Quantitative evaluation of diffusion-weighted MR imaging in the response assessment after proton-beam therapy, long-term follow-up. Radiol. Med. 2017, 122, 131-139. [CrossRef]

159. Russo, A.; Mariotti, C.; Longo, A.; Foti, P.V.; Avitabile, T.; Uva, M.G.; Franco, L.M.; Bonfiglio, V.; Milone, P.; Ettorre, G.C. Diffusion-weighted magnetic resonance imaging and ultrasound evaluation of choroidal melanomas after proton-beam therapy. Radiol. Med. 2015, 120, 634-640. [CrossRef]

160. Gordon, Y.; Partovi, S.; Müller-Eschner, M.; Amarteifio, E.; Bäuerle, T.; Weber, M.-A.; Kauczor, H.-U.; Rengier, F. Dynamic contrast-enhanced magnetic resonance imaging: Fundamentals and application to the evaluation of the peripheral perfusion. Cardiovasc. Diagn. Ther. 2014, 4, 147.

161. Francis, J.H.; Patel, S.P.; Gombos, D.S.; Carvajal, R.D. Surveillance options for patients with uveal melanoma following definitive management. Am. Soc. Clin. Oncol. Educ. Book 2013, 33, 382-387. [CrossRef]

162. Yavuzyigitoglu, S.; Tang, M.C.; Jansen, M.; Geul, K.W.; Dwarkasing, R.S.; Vaarwater, J.; Drabarek, W.; Verdijk, R.M.; Paridaens, D.; Naus, N.C. Radiological Patterns of Uveal Melanoma Liver Metastases in Correlation to Genetic Status. Cancers 2021, $13,5316$. [CrossRef]

163. Papastefanou, V.P.; Islam, S.; Szyszko, T.; Grantham, M.; Sagoo, M.S.; Cohen, V.M. Metabolic activity of primary uveal melanoma on PET/CT scan and its relationship with monosomy 3 and other prognostic factors. Br. J. Ophthalmol. 2014, 98, 1659-1665. [CrossRef] [PubMed]

164. McCANNEL, T.A.; Reddy, S.; Burgess, B.L.; Auerbach, M. Association of positive dual-modality positron emission tomography/computed tomography imaging of primary choroidal melanoma with chromosome 3 loss and tumor size. Retina 2010, 30, 146-151. [CrossRef] [PubMed]

165. Strobel, K.; Bode, B.; Dummer, R.; Veit-Haibach, P.; Fischer, D.; Imhof, L.; Goldinger, S.; Steinert, H.C.; Von Schulthess, G. Limited value of 18 F-FDG PET/CT and S-100B tumour marker in the detection of liver metastases from uveal melanoma compared to liver metastases from cutaneous melanoma. Eur. J. Nucl. Med. Mol. Imaging 2009, 36, 1774-1782. [CrossRef]

166. Orcurto, V.; Denys, A.; Voelter, V.; Schalenbourg, A.; Schnyder, P.; Zografos, L.; Leyvraz, S.; Delaloye, A.B.; Prior, J.O. 18Ffluorodeoxyglucose positron emission tomography/computed tomography and magnetic resonance imaging in patients with liver metastases from uveal melanoma: Results from a pilot study. Melanoma Res. 2012, 22, 63-69. [CrossRef]

167. Ruhen, O.; Mirzai, B.; Clark, M.E.; Nguyen, B.; Salomon, C.; Erber, W.; Meehan, K. Comparison of circulating tumour dna and extracellular vesicle dna by low-pass whole-genome sequencing reveals molecular drivers of disease in a breast cancer patient. Biomedicines 2021, 9, 14. [CrossRef]

168. Odegaard, J.I.; Vincent, J.J.; Mortimer, S.; Vowles, J.V.; Ulrich, B.C.; Banks, K.C.; Fairclough, S.R.; Zill, O.A.; Sikora, M.; Mokhtari, R. Validation of a plasma-based comprehensive cancer genotyping assay utilizing orthogonal tissue-and plasma-based methodologies. Clin. Cancer Res. 2018, 24, 3539-3549. [CrossRef]

169. Lohr, J.G.; Adalsteinsson, V.A.; Cibulskis, K.; Choudhury, A.D.; Rosenberg, M.; Cruz-Gordillo, P.; Francis, J.M.; Zhang, C.-Z.; Shalek, A.K.; Satija, R. Whole-exome sequencing of circulating tumor cells provides a window into metastatic prostate cancer. Nat. Biotechnol. 2014, 32, 479-484. [CrossRef] 